\title{
Tank 48H Waste Composition and Results of Investigation of Analytical Methods
}

by

D. D. Walker

Westinghouse Savannah River Company

Savannah River Site

Aiken, South Carolina 29808

\section{MASTEP}

DOE Contract No. DE-AC09-96SR18500

This paper was prepared in connection with work done under the above contract number with the U.S. Department of Energy: By acceptance of this paper, the publisher and/or recipient acknowledges the U.S. Government's right to retain a nonexclusive, royalty-free license in and to any copyright covering this paper, along with the right to reproduce and to authorize others to reproduce all or part of the copyrighted paper. 


\section{DISCLAIMER}

This report was prepared as an account of work sponsored by an agency of the United States Government. Neither the United.States Government nor any agency thereof, nor any of their employees, makes any warranty, express or implied, or assumes any legal liability or responsibility for the accuracy, completeness, or usefulness of any information, apparatus, product, or process disclosed, or represents that its use would not infringe privately owned rights. Reference herein to any specific commercial product, process, or service by trade name, trademark, manufacturer, or otherwise does not necessarily constitute or imply its endorsement, recommendation, or favoring by the United States Government or any agency thereof. The views and opinions of authors expressed herein do not necessarily state or reflect those of the United States Government or any agency thereof.

This report has been reproduced directly from the best available copy.

Available to DOE and DOE contractors from the Office of Scientific and Technical Information, P.O. Box 62, Oak Ridge, TN 37831; prices available from (615) 576-8401.

Available to the public from the National Technical Information Service, U.S. Department of Commerce, 5285 Port Royal Road, Springfield, VA 22161. 


\section{DISCLAIMER}

Portions of this document may be illegible electronic image products. Images are produced from the best available original document. 


$$
\begin{aligned}
& \text { WSRC-TiR-97-0063 } \\
& \text { ReV.0 }
\end{aligned}
$$

RECORDS ADMINISTRATION

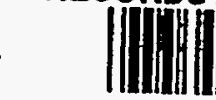

TANK 48H WASTE COMPOSITION AND

RESUTTS OF INVESTIGATIONS OF

ANAIYTICAL METHODS (U)

D. D. WAIKER, W. T. BOYCE, C.. J. COLERAN, D. P. DIPRETE, T. B.. EDWARDS, A. A. ERECEUKWU, C. W. HSU, S. F. PETERSON, I. I. TOVO, and 4 . J. TEITAKER

Publication Datè Apri1, 2, 1997

Hestinghouse Savannah River Company Savannah River site

Alken, SC 29.808 


\section{APRROVAIS}

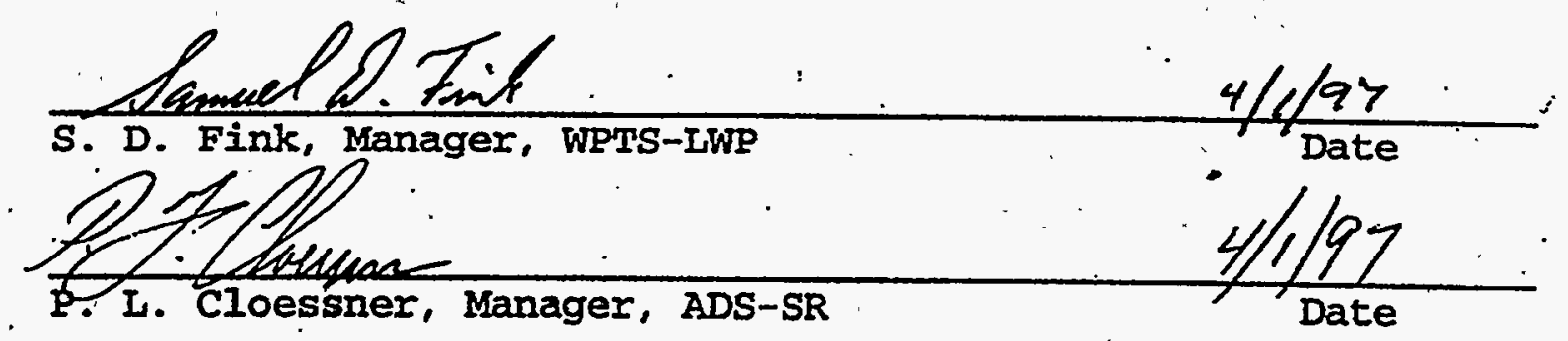

J. C. Griffit, Manager, ADS-ARR

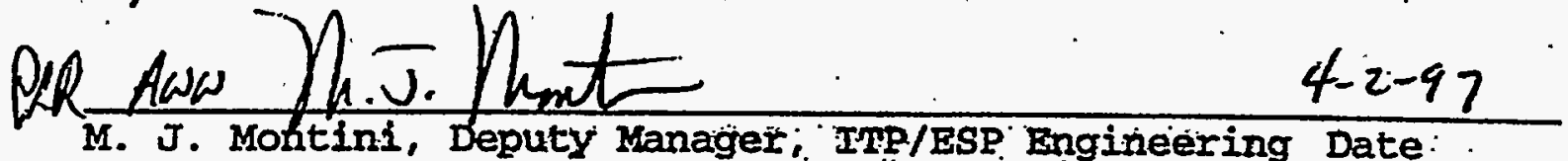

M. J. Montini, Deputy Kanager; Twp/ESP Engineering Date:

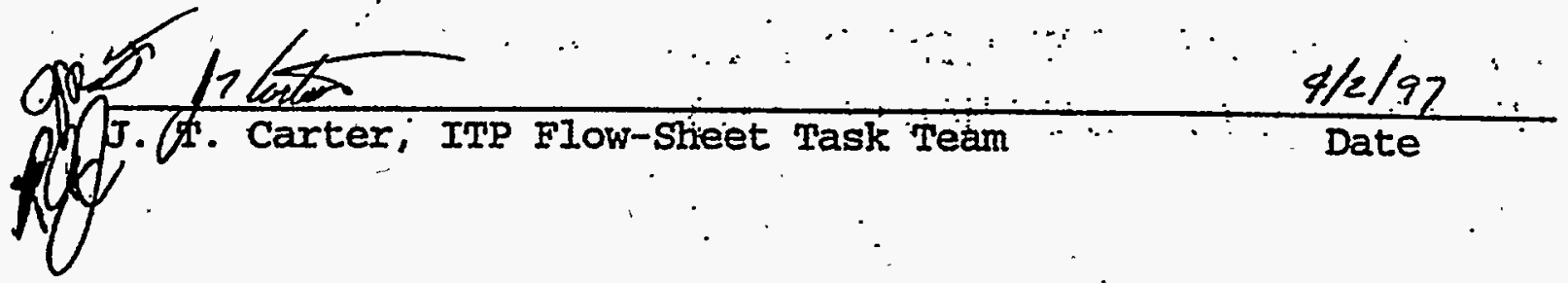




\section{$\because$ CONTENTS}

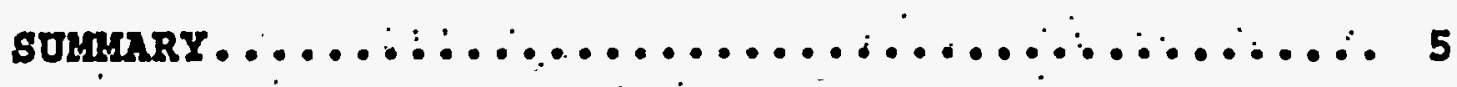

INTRODUCTIOW: ...................... 6

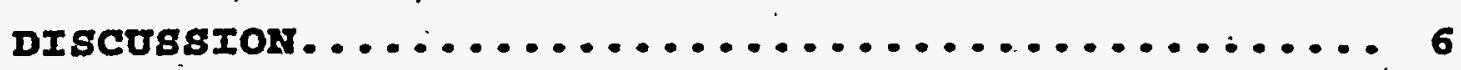

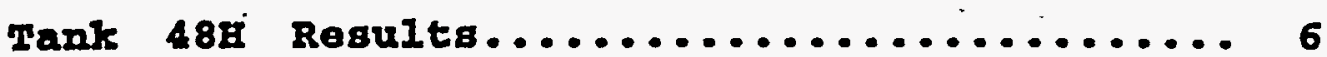
Variability Study on ADS Routine Methods.... 7

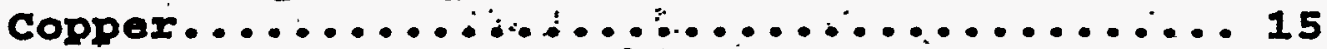
Weight Percentage solida.............. 16

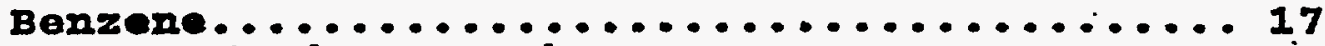
Salt solution Density................. 20

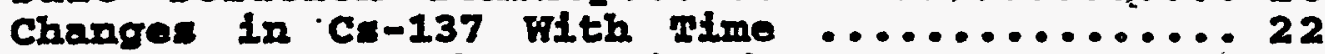
Cs-137/Total Cesium Ratio in Tank 48B......24 concrusions. ...................... 25 QUALITY ASSURANCE .................... 26 REFERENCES ........................ 26 APPENDIX A: Analytical Mathoda............ 27 ARPENDIX B. statistical Analysis........... 29 


\section{IIST OF FIGURES}

1 Cesium-137 Concontration in Tank 48H.......

2 Potassium Concentration in Tank 48H....... 9

3 Phenylboronic Acid Concentration in Tans $48 \mathrm{~g}$

4 Cesium-137 Concentrations in Tank 48H...... 24

\section{IIST OF TABLES}

I. Tank 48H supernate Composition April to

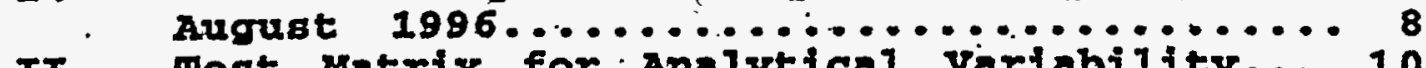

II. Test Matrix for Analytical variability.... 10

III. Results from variability study of ADS

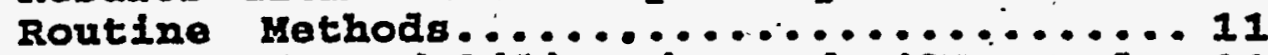

IV. Sources of Variability in Tank 48B Results 11

v. Effect of Autosamplex Shield on Free Hydroxide Results...................14

VI. Copper Concentration in Tank 48H Filtrate: 15

VII. Weight Percentage solids in Tank 48E..... 16

vIII. Benzene Concentrations in Tank 48H-Samples 1.8

IX. Variability of. Benzene Heasurements...... 18

x. Tank 48E simulant Composition..........21

XI. Density of Tank $48 \mathrm{~B}$ simulent at $23{ }^{\circ} \mathrm{C} \ldots . .21$

XII. Comparison of Predicted and Measured Sodium Concentrations in Tank 487 Solutions.....21

XIII. C8-137 Concentrations in Tank 48B samples. 23

XIV. Cesium Content of Tank 48 slurxy.........24. 


\title{
TANK - 48H WASTE COMPOSITION AND RESULTS OF INVESTIGATIONS OF ANALYTICAL METHODS (U)
}

\author{
BY D. D. HALKER, W. T. BOYCE, C. J. COTEMAN, \\ D. P. DIPREIE, T. B. EDWARDS, A. A. EKECHUKWU, \\ C. W. HSU, S. F. PETERSON, I. I. TOVO, \\ and H. J. WHITAKER
}

\section{SUMUART}

This report serves two purposes. First; it documents the analytical results of Tank 48H samples taken between April and August 1996. Second, it describes investigations of the precision of the sampling and analytical methods used on the Tank $48 \mathrm{H}$ samples.

Analytical results for five Tank $48 \mathrm{H}$ sampling dates between ApriI and August of 1996 are reported. This time period followed the removal of the majority of the benzene from Tank 48H and preceded the start of the Process Verification Test. Phase 1,(PVT-1).. The major composition changés in Tank 48H were slow increases in the Cs-137 and potassium concentrations and a rapid decrease in the phenylboronic acid (IPB) concentration.

Investigations of the accuracy and precision of sampling and analytical methods used on the Tank 48H samples revealed the following.

- Routine analytical methods for Cs-137, free hydroxide, boron, potassium, nitrate, nitrite, and phenol have uncertainties of 118 or smaller.

- An unusual variability in the free hydroxide method was identified by this study which led to an instrument modification to correct the problem.

- Variability due to delays in analysis are small or nonexistent for most analytes. However, this depends on the rate of reactions of interest and this data was obtained when there were no rapid changes occurring in Tank 48H.

- The soluble copper concentration in Tank 48H samples taken between October 1995 and November 1996 varied between $<.3$ to $1.6 \mathrm{mg} / \mathrm{L}$ with no apparent consistent trend. 
- The solids content in Tank $48 \mathrm{H}$ samples averaged $2.30 \pm .36$ wt 8 compared to an expected value of 2.7 wt $\%$. The variability in this measurement is due to both tank sampling and the analytical method.

- The method for benzene measurements in radioactive slurries has a variability of $\pm 35 \%$ and a bias of -708 . Several actions for improving this method are identified.

\section{INTRODUCTION}

The In-Tank Precipitation (ITP) process at the Savannah River Site (SRS) prepares high level radioactive waste for vitrification in the Defense'Waste Pröcessing Facility (DWPF): In Tarik $48 \mathrm{H}$ of the ITP facility; cesium-137 and strontium-90 are-removed from solution using two specialty chemicals, sodium tetraphenylborate (NaTPB) and monosodium titanate (MST). Sodium tetraphenylborate precipitates cesium and potassium. The MST removes strontium, uranium, and plutonium. The insoluble species are concentrated and washed using crossfiow filters. Decontaminated filtrate is transferred to Tank $50 \mathrm{H}$ for ultimate disposal by the Saltstone facility. The concentrated cesium- and strontiumcontaining waste is transferred to Tank $49 \mathrm{H}$ for storagie until processed for vitrification by the Late Wash Facility and DWPF.

During september 1995, IT⿱宀 began radioactive operations by adding NaTPB solution to radioactive waste in Tank $48 \mathrm{H}$. Between October and November 1995, benzene from the decomposition of NaTPB was detected in the Tank 48H vapor space. During November and December 1995, approximately $10,000 \mathrm{~kg}$ of sodium tetraphenylborate decomposed, leaving. $20,000 \mathrm{~kg}$ of potassium and cesium tetraphenylborate in the tank. The rapid decomposition of NaTPB appears to have been caused by a combination of factors, including the high tank temperature and presence of copper and possibly other catalysts. ${ }^{2}$ After it was estabilished that the insoluble KTPB and CSTPB were decomposing at a slow rate, the benzene accumulated in the tank was removed by carefully mixing the tank contents.

Analytical results for sámples taken from.Tank $48 \mathrm{H}$ from September 1995 until April 1996 were reported previously.2 Sampling continued at a reduced frequency from April 1996 until August 1996. The results from those samples are reported below.

In addition, investigations into the accuracy and precision of the analytical methods were undertaken. The analyses were provided by the Analytical Development Section (ADS) and Interim Waste Technology Section (IWTS, now called Waste 
Processing Technology Section, WPTS) within the Savannah River Technology Center.

\section{DISCUSSION}

\section{Tank 48i Sample Results}

Analytical results on filtered portions of the Tank $48 \mathrm{H}$ samples taken between April and August 1996 are shown in Table I. Results prior to April 1996 and following August 1996 were reported previously. ${ }^{1-2}$ The analytical methods are described in Appendix A. Several components showed significant changes in concentration during the four-month period.

Cesium-137 increased slowly and the rate accelerated in August (Figure 1). The acceleration was verified in a sample taken prior to the start of the PVT-1 test on, November 3, 1996. The reason for the increase in rate has not been determined but is under investigation by SRTC. The samples taken on April 13, 1996, showed Cs-137 concentrations significantly higher than the trend in previous and subsequent samples. Additional samples were analyzed to. investigate the cause of the high values and the results are discussed in the section titled "Changes in Cs-137 with Time:" Potassium increased proportionally to cesium (Figure 2) as the tetraphenylborate solids in the tank slowly. decomposed.

Phenylboronic acid decreased by more than 908 between April and August 1996 (Figure 3). This is largely due to the decomposition, but some of the change is attributable to dilution of the tank contents by purm seal water leakage.

Free hyaroxide, nitrate, and nitrite ion decreased in concentration. 'Although the decreases are due largely to dilution of the tank contents, adsorption of caribon dioxide and radiolytic decomposition reactions may also contribute to their decline.

The density of the solution decreased with time due to dilution of the waste with pump seal water. A correlation between density and the total salt concentration (expressed as the sodium ion concentration) is discussed in a later section of this report.

\section{Variability study ó ADs Routine Hethods}

Table I listed the results from routine analytical methods provided by the Analytical Development Section of SRTC. The variability of the results was investigated using a set of three Tank 48H VDS samples. These samples were taken from the tank over six days (August 5 to August 11; 1996). Based on the slow trends in composition shown in Table 1, the tank 
Table I. Tank 48H Supernate Composition Apri1. to August 1996

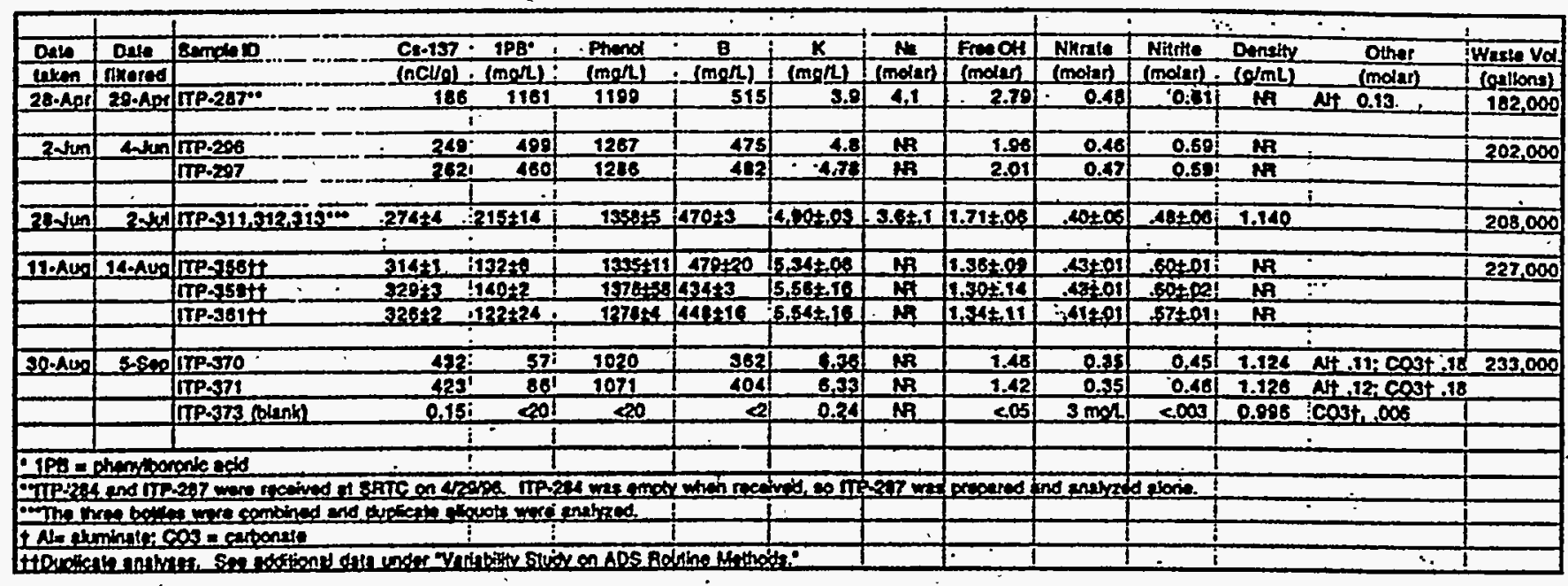

Figure 1. C8-137 Concentration in Tank 48H

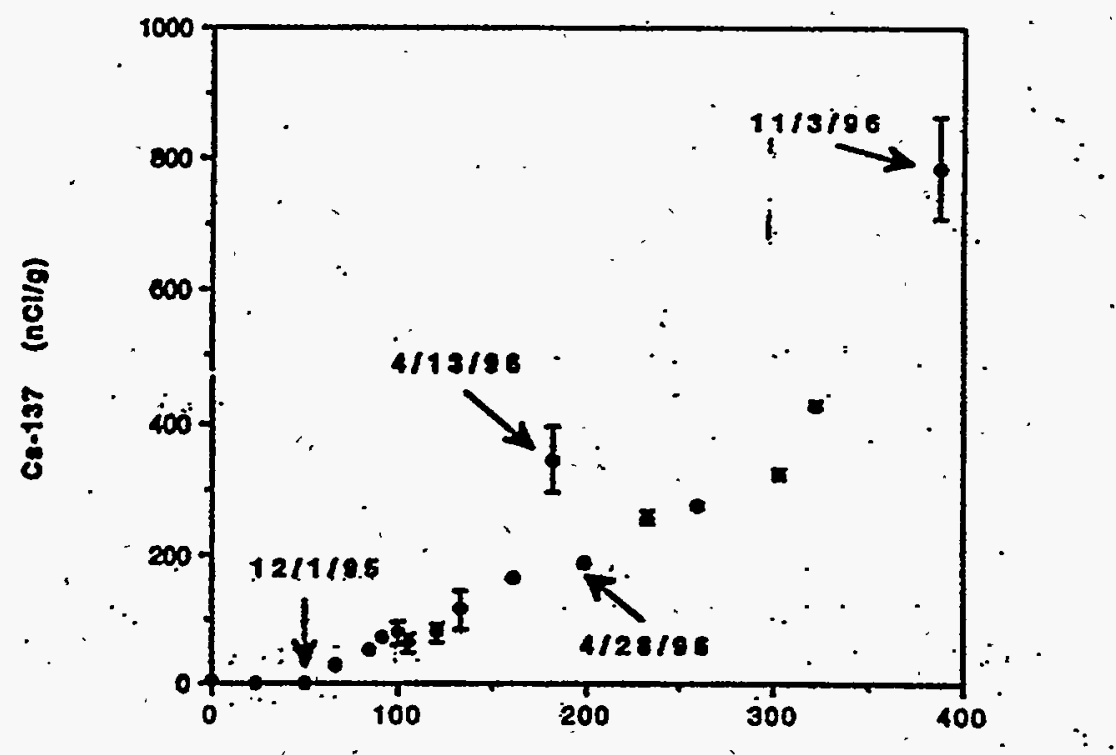

Elapsed Time since 1 Oet 95 (gays) -

Note: See Reference 1 for data from 0-190 days. See Reference 2 for datum on $11 / 3 / 96$. For remaining data, see ... Table I of this report. 
Figure 2. Potassium Concentration in Tank 48E.

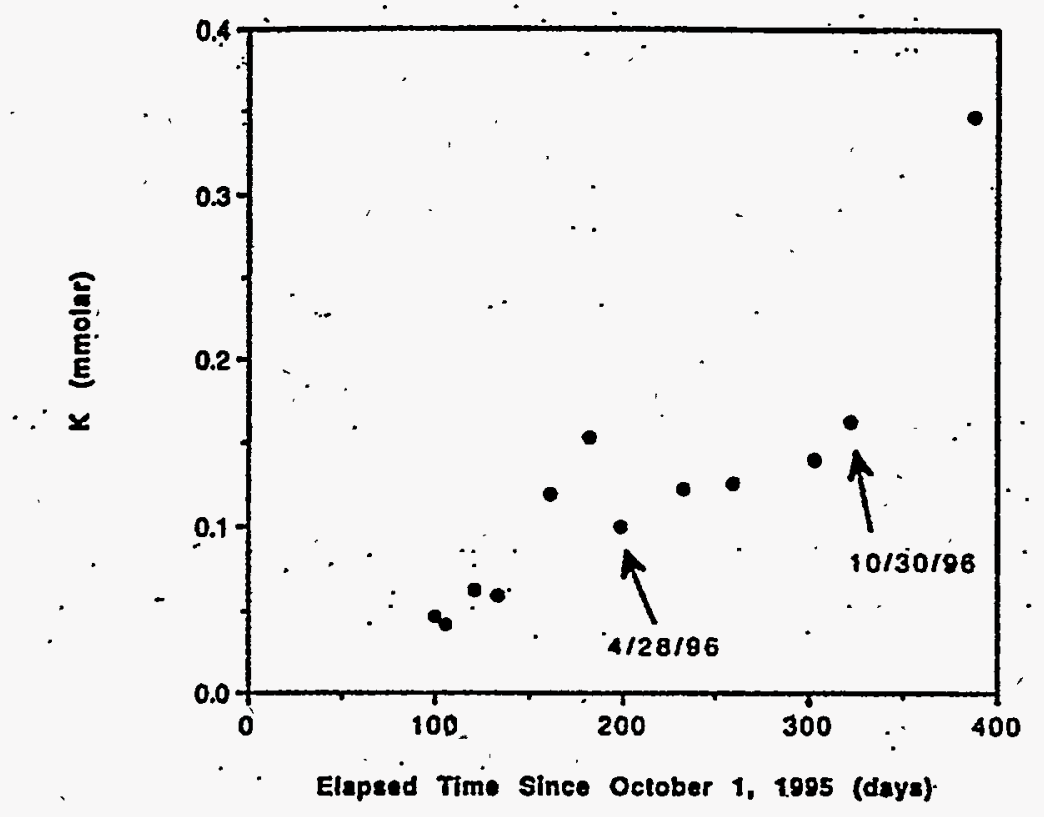

Figure 3. Phenylboronic Acid Concentration in Tank $48 \mathrm{H}$

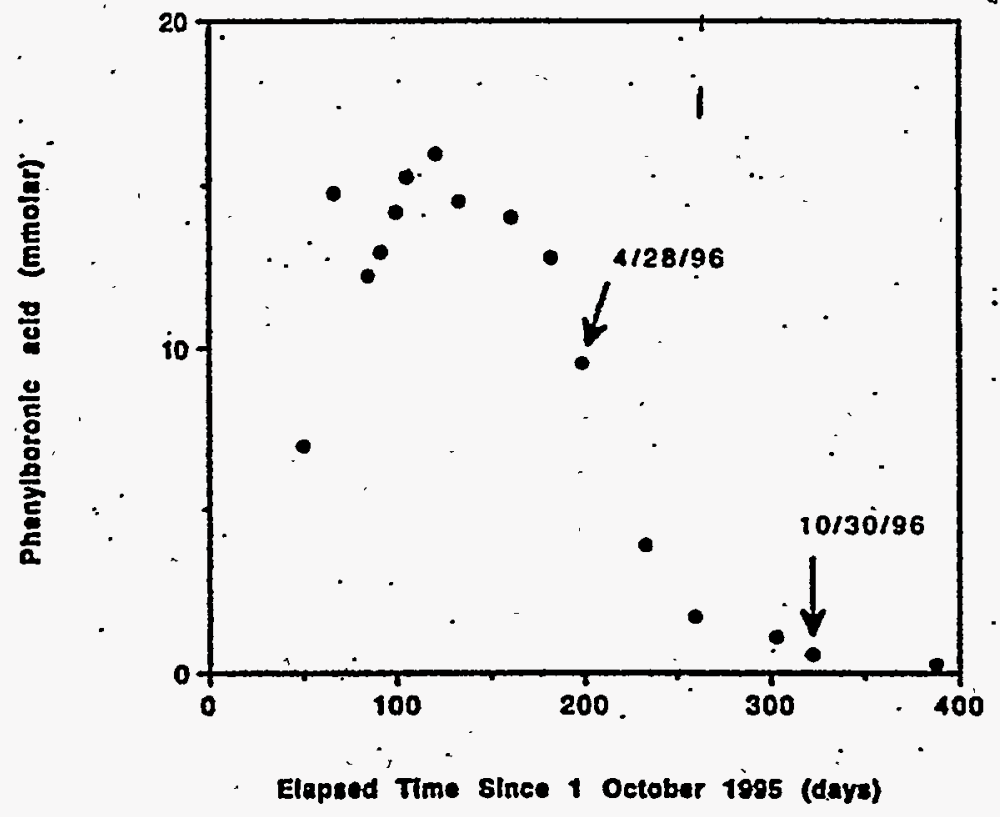


Dato

\section{Sampiling} ITP-356

$8 / 14 / 96$.

$8 / 20 / 96$

$8 / 26 / 96$.
Order (submission ITP-359

$1(3), 3(6)$

$1(3), 5(5)$

$2(2), 5(4)$
Order) **

ITP-361

$4(1), 6(4)$

$2(4), 3(6)$

$1(5), 6(6)$.

\section{Analyses Requested}

Cesium-137

Frée hydroxide Boron
Nitrate

Ni.trite

Potassium
Phenol

Phenylboronic acid(IPB)

*Numbers without parentheses indicate the order in which the samples were taken. Numbers in parentheses indicate the order in which the samples were submitted for analysis.

composition did not change measurably over the six day period. Therefore, differences in results should reflect sampling and analytical variability. This investigation measured:

(1) total variability,

(2) differences between VDS bottles,

(3) differences between samples removed from the same VDS bottle, and

(4) differences caused by delays in analyzing samples.

A statistically designed test was performed in which three VDS bottles from Tank 48H (ITP-356, ITP-359, ITP-361) were sampled in duplicate on each of three dates over a period of twelve days. The sequence of taking samples and of submission to ADS was randomized within each sampling date. Typically, samples are analyzed by ADS in the order in which they are submitted. The test matrix is shown in Table II. This test was not designed to measure the accuracy of the methods, but rather the precision.

Table III lists the results from all analyses. Table IV provides a summary of the sources of variability. Appendix B gives the details of the statistical analysis of the data.

The data set was analyzed for the total percentage relative standard deviation (8RSD). and the components of variation contributing to the total. The results are shown in Table IV. The 8 RSD is the standard deviation of the measurements expressed as a percentage of the average of the measurements. It's magnitude indicates how close another measurement will be to the average values in Table III. 
TABLE III. Results from Variability study of ADS Routine Methods

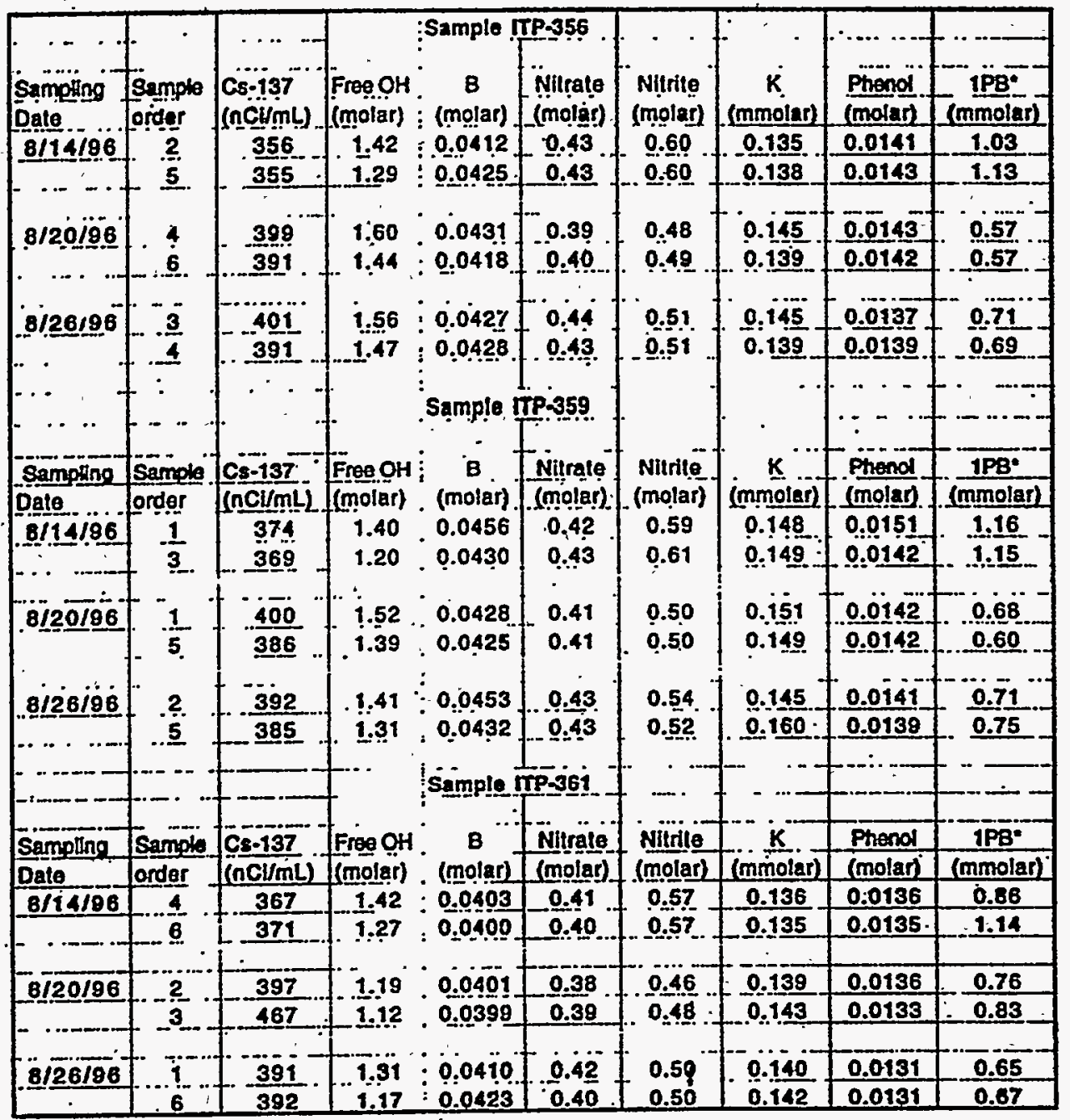

TABLE IV. Sources of Variability in Tank 48 Results

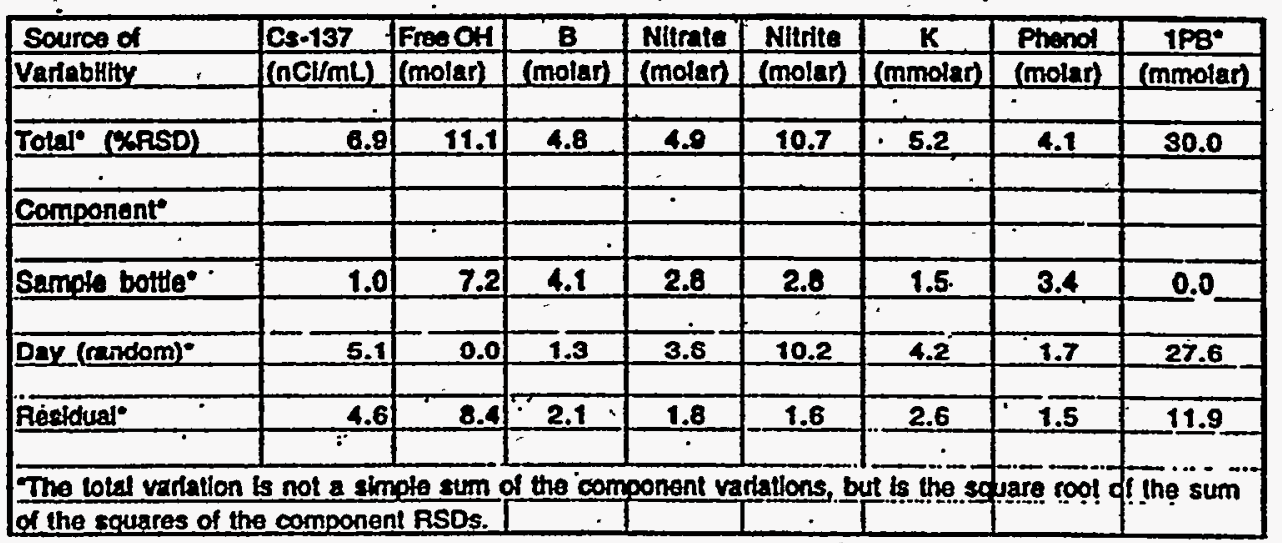


The total 8RSDs for all of the analytes except 1 PB were 118 or smaller (1-sigma or $67 \%$ confidence interval). This range of values is very similar to previously reported results for Extended Sludge Process (ESP) test samples. ${ }^{3}$ The high variability for free OH (11.18) results from an instrument problem discovered by this study and described below. The relatively high variability for nitrite (10.7\%) remains unexplained and is particularly puzzling given the lower variability of nitrate (4.9\%). The two compounds are measured simultaneously. on the same instrument. The high variability for 1PB results from a time-dependent decrease in the concentration (see below) and to the low concentration. The average concentration $(0.81$ molar) was only four times the detection Iimit $(0.2$ molar). The 1PB peak in the HPIC trace tails more than phenol, causing greater uncertainty in the peak integration at levels close to the detection.limit. Subsequent to this study; a modification of the method has improved the sharpness of the $1 \mathrm{~PB}$ peak and may have decreased the variability at low concentrations.

In five of the eight routine methods studied, the majority of the total RSD results from day-to-day variations. This source includes day-to-day variations in instrument performance (calibration, operator, standards) and sample preparation (other than removing the subsample from the VDS bottle). The three exceptions are free $\mathrm{OH}^{-}$. boron, and phenol: The variability in free oH was traced to an instrument problem discussed below. For boron and phenol, the total variabilities were so low ( 4.8 and 4.1 \%) that identifying the individual sources is of. little importance:

Differences between vDS bottles were statistically significant for five of the eight analytes. However, the differences were small (<48) except for free oH (which was only 7.2\%). Iow variability for soluble components between samples taken from a well-mixed waste tank is-expected. However, this result may not be true for insoluble components (see below under. "Weight Percentage Solids"). Since the samples were taken on separate days with mixing in between, this result supports the assumption that samples are beirig removed from a well-mixed region of the tank (although it does not prove; that the entire tank is well mixed).

The residual RSD includes differences between duplicate subsamples taken from a VDS bottle on the same day. It also includes aspects of sample preparation and analysis that vary from minute-to-minute but not day-to-day. Although this source was a significant fraction of the total variability for several analytes, they were small $(<5 \%)$ except for free OH $(8.48)$ and $1 \mathrm{~PB}(11.98)$. These results confirm that reproducible samples of soluble components can be removed from a VDS bottle. The behavior for free OH and 1PB could be due to subsampling from the VDS bottle, although this is unlikely since components that were analyzed are soluble and 
the bottle is easily mixed by shaking. It is more likely that the residual RSD indicates significant variability (subsample-to-subsample) in the sample preparation or instrument. For 1PB, this includes the extraction performed in the sample preparation. For free OH, the source was traced to $a$ instrument problem discusșed below.

The day-to-day variability discussed above was further investigated to determine if there were consistent trends with time. Trends were observed for five analytes, although in most cases these were $<4 q$ change in twelve days. "Two analytes, 1PB and nitrite, showed larger trends. Qualitatively; these results suggest that samples should be analyzed as soon as possible after removing them from the tank. Quantitatively, however, the magnitudes of the trends for most analytes indicate delays of up to two weeks are not important. There is no single recommendation for analytical turnaround times that applies in all situations. The rates of reactions of interest must be considered and these can vary considerably in the tank. Furthermore, the data below. does not provide an answer to the question of whether the analytical results should apply to the tank on the day the sample was taken or on the day the analysis was performed. Again, for most analytes the difference is insignificant, but for others (such as IPB and nitrite), it may be important.

The free hydroxide concentration in two of the sample bottles trended upward and one trended down. When the data from all three bottles are considered together, no significant trend was found. It is-expected that hydroxide will trend downward over long time periods due to disorption of carbon dioxide from the air and depletion from radiolytic decomposition of tetraphenylborate compounds. The results from this experiment indicate that the downward trend is not sighificant over a twelve day interval.

The phenol concentration in each bottle trended down. When al1 three were considered together, the downward trend was statistically significant (-.04 molar per day) . However, over a two week period, this change is only -0.3 mmolar, or only a $2 \%$ change in the phenol concentration. The only likely chemical explanation for a downward trend in phenol is decomposition from radiolysis. over a two week period, this trend.is. not important for most uses of the data.

The boron concentration in two sample bottles trended upward and one was virtually flat. Taken together, the trend was not significant. It is expected that a long-term increase will occur in the boron concentration due to slow decomposition of the tetraphenylborate solids. "The rate of increase in boron should mimic increases in Cs-137 and potassium. The change in potassium (Figure 3) indicates that the boron should increase by 0.005 mmolar per day. Over a 
two week period, this corresponds to a change of lesis than $0.2 \%$ of: the average boron concentration.

For nitxite, none of the individual bottles showed a significant trend, but when taken together, a downward trend was statistically significant $(-.006$ molar/day, or $-14 \%$ over twelve days). The long-term trend in Tank 48H has been downward due largely to dilution of the waste by pump seal water. In addition to dilution, radiolysis of the waste solution converts nitrate into nitrite." In the presence of organics, nitrite is converted to nitrous oxide and ammonia." Thus, nitrate will decrease, but nitrite can increase or decrease depending on the relative rates of production and destruction. At the current radiolysis rates in the tank, the reactions are expected to be slow and not detectable. A detailed analysis of the data may reveal a trend in the tank when corrections for dilution are included. However, the ratio of nitrate to nitrite does not appear to have changed since October 1995. The data from this test. suggests that nitrite undergoes a more rapid decrease in the sample bottle than occurs in the tank. However, due to the small size of the data set, it is suggested that this result be confirmed before significant changes are made to sampling and analysis plans.

The concentration of IPB trended down in all three bottles. When considered together, the downward trend was statistically significant (-.03 molar/day). This: trend is expected since the 1PB concentration in Tank 48H dropped by over 908 during the three month period that included the variability test (Figure 3). This downward trend explains. much of the large day-to-day variation (27.68) for 1PB shown in Table IV. From the fitted line regressing 1PB over time, the root mean square error (the sigma for the scatter about the line), is 0.142 molar. At day $=0,1$ PB was approximately 1 mnolar, so the random error is only 14.28 after accounting for a linear decrease in concentration with time compared to 27.68 if the decrease with time is neglected.

The results were examined for a dependence on the order of submission (i.e.. ADS LIMS number). Typically, samples submitted as groups axe analyzed in the order submitted. Free hydroxide was the only method that showed a statistically significant trend, decreasing in the order in which they were analyzed. This trend was traced to an autosampler located in a radiohood. It appears that the high air flow rate over the samples awaiting analysis resulted in significant. adsorption of carbon dioxide during the time required to run a set of six samples (approximately 45 minutes). Surprisingly, standard.. solutions placed at the beginning and end of sample sets did not show the effect. The problem was corrected by erecting a wind shield around the samples. Table $v$ shows results for the same set of samples with and without the shield in place. With the shield in place, the average value 
Table v. Effect of Autosamplex shiola on Free $\mathrm{OH}^{-}$

order of sample

Analyeis

1
2
3
4
5
6

4

5

6.
ITP-356

ITP-359

ITP-356

ITP-359

ITP-361

Average

ITP-361

Standard Dev.

Hree Hydroxide (molar)
Without ghield
Hith ghieid

of the results increased by 0.32 molar and the variability decreased by an order of magnitude.

\section{Copper}

Copper concentrations in filtered samples from Tank 48H have been measured on three occasions by inductively coupled plasma emission spectroscopy (ICP-ES). The results are shown in Table VI. In December 1.995, several samples were prepared, analyzed, and result's reported. ${ }^{1}$ Although the combination of very low copper concentration $(-1 \mathrm{mg} / \mathrm{I})$ and high salt concentration made the analysis very difficult,. quality assurance measures taken at that time indicated the results were dependable. In July of 1996, additional samples and some of the previous samples were submitted for analysis. and problems were encountered with low recoveries when the samples were spiked with $1 \mathrm{mg} / \mathrm{L}$ copper. The results of the July analyses are included in Table VI for comparison. When the problem was encountered, a program was initiated to identify and correct the problem with the low spike recoveries. The problem was corrected by a modification to the sample preparation to ensure the highly alkaline samples were made sufficiently acidic to keep copper in solution. (at the sacrifice of sensitivity due to additional dilution).. The original and additional samples were analyzed by the new procedure in February 1997. The results for the three analysis dates are quite consistent, indicating that the differences are real and are not due to analytical variability. They may resuit from time-dependent changes in the tank composition (chemistry effect) or from inhomogeneities in the tank (sampling problem). "Examples of chemistry effects are solubility, adsorption; and complexation. Copper is believed to shift between two oxidation state during the tetraphenyiborate decomposition reaction. If there are significant differences in the solubility, adsoxption properties, or complexation between: $\mathrm{Cu}$ (I) and $\mathrm{Cu}$ (II), the changes in the tank may reflect changes in the $\mathrm{Cu}$ (I)/Cu(II) ratio. Understanding the changes is not important if soluble copper at 0 to $1.5 \mathrm{mg} / \mathrm{L}$ is not the 
Table vI. Copper Concentration in Tank $48 \mathrm{~B}$ Filtrate

sameis

Date analyzed:

Cii concentration (mo/L)

10/12/95 (ITP-164)

$11 / 7 / 95 * *$

12/1/95 (ITP-208)

$12 / 18 / 95$ (ITP-216/217)

2/10/96 (ITP-245)

$2 / 10 / 96$ (ITP-246)

$4 / 13 / 96($ ITP-278/79/80/81)

$4 / 13 / 96$ (ITP-278).

$7 / 96($ ITP-320-25, 328-3.31)

11/3/96 (ITP-382) $12 / 95 *$

$7 / 96$

$2 / 97$

Tank 49H (ITP-276)

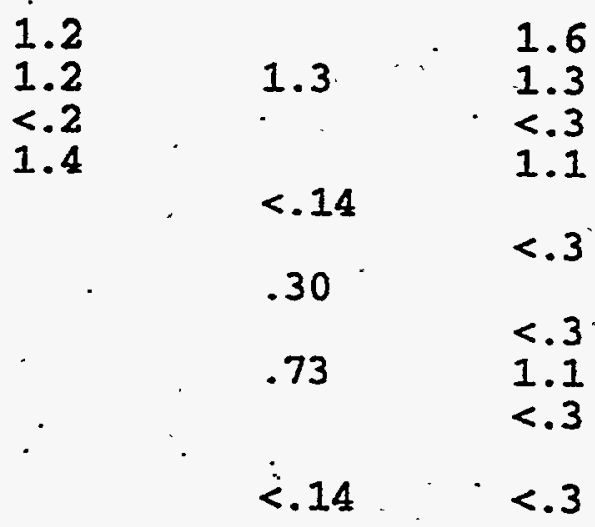

*Data reported previously in Reference 1.

* Sample from the second filtration run, Filtrate Hold Tank \#5, obtained from the ITP laboratory (Sample\#51013 dated $11 / 7 / 95)$.

tobtained from combining the indicated samples. For the 7/96 combined sample, the original samples were taken on three. different days $(7 / 13,7 / 14$, and $7 / 17)$.

"Datum reported previously in Reference 2

dominant decomposition catalyst. Nevertheless, Tank $48 \mathrm{H}$ should continue to be monitored periodically for soluble copper. In addition, monitoring copper during simulant tests should be considered since it could reveal chemical effects.

In addition to the Tank $48 \mathrm{H}$ samples shown in Table VI, Tank $49 \mathrm{H}$ solution was analyzed twice and no copper was detected either time.

Teight Percentage" solids

The insoluble solids concentration in Tank $48 \mathrm{H}$ was 2.30 wt (士.34) in August 1996. This result is the average of seven measurements of five VDS sarmles (Table VII). It is consistent with estimates of the tank solids content from. previous measurements. The weight percentage solids in Tank. 48H slurry samples is measured in the Shielded Cells facility by a gravimetric method (see Appendix A).

The variability in the measured solids concentration helps determine the consistency of the Tank 48H sampling procedure and the analytical method. Because the solids tend to settle or float in Tank 48H (depending on the density of the salt solution), it is very difficult to obtain a representative 
Table vII. Woight Percentage solid in Tank 48H.

$\begin{array}{lll}\text { Samp1e } & \text { Pate } & \text { Solidgint } x) \\ \text { ITP-356 } & 8 / 5 / 96 & 2.87 \\ \text { ITP-359 } & 8 / 10 / 96 & 2.28 \\ \text { ITP-360 } & 8 / 11 / 96 & 2.59,2.15,2.32 \\ \text { ITP-361 } & 8 / 11 / 96 & 2.02 \\ \text { ITP-371 } & 8 / 30 / 96 & 1.87\end{array}$

Average of 7 measurements: 2.30

Variability: $\sigma$ (sample-to-sample) 0.28 (128)

$\sigma$ (analytical) $\quad 0.22(108)$

total $\because 0.36(168)$
ITP-373* $8 / 30 / 96 \quad 0.012$
SL-96-10** $1.60,1.35$
Average of two measurements: $\quad 1.48$
variability $\quad \therefore, \ldots, \quad \pm .18$

*ITP-373 was a blank sample (distilled water).

**Nominal 2 wt 8 slurry prepared from reagent grade

chemicals. Analysis of the control in a non-radioactive laboratory yielded $1.77 \pm .09$ wt $\%$.

sample. It proves necessary to mix the tank contents with slurry purms, stop the pumps; then quickly obtain the sample before the solids settle slgnificantly. During mid1996, numerous samples were taken from Tank $48 \dot{H}$ and sent to SRTC for analysis and experiments. The sampling method, yielded obviously low or no solids in almost half of the samples. A modification to the sampling procedure (mix, then sample within two hours) greatly improved the consistency of the samples so that all appeared to have significant amounts of solids present. Following the modification, several samples were analyzed to determine the precision of the analysis method and of the tank sampling method. The results are shown in Table VII. Over the period in which the samples were taken $(8 / 5$ to $8 / 30)$, the tank volume-increased slightly (48). The total random variability (ignoring the dilution) is 16\%, with approximately equal contributions from the analytical method and Tank $48 \mathrm{H}$ sampling variability. Thus, improvement of the reliability of the results can be obtained by improvements in both sampling and analysis. The analytical method also appears biased low by $15 \%$ (compared to the control slurry SL-96-10). This should also be investigated in any attempt to improve the analytical method.

The expected solids concentration in Tank $48 \mathrm{H}$ can. be: calculated from previous measurements. Prior to addition of NaTPB in September 1995, an extensive tank sampling program 
estimated that the solids content of the tank was 0.55 wt 8.5 The tank contained 460,000 gallons of waste with an average density of $1.24 \mathrm{~g} / \mathrm{mL}$, corresponding to $11,900 \mathrm{~kg}$ of solids. Addition of NaTPB in September 1995 created $14,000^{\circ} \mathrm{kg}$ of additional KTPB solids, for a total of $25,900 \mathrm{~kg}$ of solids. The majority of the solids are KTPB with a density of 1.18 $\mathrm{g} / \mathrm{mr}$. These solids account for approximately 5600 gallons of the tank waste volume. In August 1996, the time period for the sample results in Table VII, the slurry volume was 227.000 gallons with a solution density of $1.13 \mathrm{~g} / \mathrm{mL}$ (Table 1). The estimated solids content is 2.7 wt $\%$, which agrees within $15 \%$ of the measured value.

These results indicate that the current sampling and measuring method is accurate to about $\pm 158 .$. There is currently no required need for this analysis. As currently performed, the procedure measures the combined. tetraphenylborate, titanate, and sludge insolubles. It does not satisfy the process requirement to measure the weight percentage of $\mathrm{K} / \mathrm{Cs}$ tetraphenylborate solids in transfers from Tank 49H to S Area. ${ }^{6}$ A potential application is to use it in conjunction with the benzene analysis to improve the estimates of the tank benzene inventory. It is probably sufficiently accurate for this purpose. No further development of this analysis is recommended until a. requirement and accuracy are defined.

\section{Benzene}

Several vDs bottles have been analyzed for benzeñe by $a$. method designed to measure easily evaporable benzene. The. method was intended to estimate the amount of benzene. in Tank $48 \mathrm{H}$ that could evaporate rapidiy when the pumps were running. The method is described in Appendix A: The results (Table VIII) indicate that the tank contained 2,000 to $6,000 \mathrm{~kg}$ of benzene. However, because of the poor reproducibility of the method, the information was thought not to be reliable.. In retrospect, the results did indicate the correct order of magnitude and the method did reflect the loss of the benzepe from tank mixing during April and May 1996. However, the large variability severely limits the usefulness of the data.

Identifying the source of the variability can direct attempts to improve the method. The variability may be due to the analytical method, differences in tank samples, or both. Samples taken between January and June 1996 did not contain representative portions of solids because the tank could not be stirred immediately prior to sampling. Benzene associategd with the insoluble solids in the tank and differences in the solids content could account for the variability in benzene concentrations. Solids measurements were not made on the bottles used for the benzene analysis so the results could not be corrected for differences in solids content. 
Table VIII. Benzene Nialyaes on Tank 48E Samples*

\begin{tabular}{ccc} 
Dete & Samp1e & Benzene $(\sigma / 4)$ \\
\hline $1 / 21 / 96$ & ITP-235 & 6.3 \\
$1 / 26 / 96$ & ITP-239 & 3.1 \\
$2 / 10 / 96$ & ITP-245 & 4.1 \\
& ITP-246 & 9.7 \\
$3 / 22 / 96$. & ITP-267 & 4.4 \\
& ITP-268 & 2.8 \\
$4 / 13 / 96$ & ITP-280 & 0.41 \\
$5 / 4 / 96$ & ITP-286 & 0.021
\end{tabular}

*Results through 4/13/96 were reported in Ref.1.

TABLE IX. Variability of Benzeñe Heasurements.

Elapsed Time

(days)

Iocation

0 Laboratory

1 Laboratory

1

7

14
Shielded Cells

Shielded Cells

Shielded-Cells
Messured Benzene

SIurry $\mathrm{A}$

$(2.2 \mathrm{~g} / \mathrm{kg})$ *

$1.8,2.3$

$1.7,2.2$

0.4

1.0

$0.7,0.8$
Concentration. ( $\sigma / \mathrm{kg})$ Sluxry $B$ $(10.8 \mathrm{~g} / \mathrm{kg})$ * $6.1,4.4$

$10.9,10.2$

3.1

2.0

$4.0,2.5$

*The slurries were spiked with 2.2 and 10.8 grams of benzene per $\mathrm{kg}$ of slurry. The slurry density was $1.13 \mathrm{~g} / \mathrm{mL}$.

Subsequentiy, an experiment using simulated slurxy was undertaken to estimate the variability associated with the method of analysis. The results of this test are shown in Table IX. A non-radioactive slurry simulating the Tank 48H composition ( 5 wt $\% \mathrm{KTPB}$ and $3 \mathrm{M} \mathrm{Na}{ }^{+}$salt solution) was placed into two VDS bottles and spiked with 2.2 and $10: 8$ grams of benzene per kilogram of slurry. The spike was added via syringe through the rubber septum in the cap of each VDS bottle. After shaking briefly, the samples were analyzed. The samples were allowed to sit overnight at room temperature and were analyzed a second time on the following day. They were placed into the Shielded Cells and the procedure used on the Tank 48H samples initiated. The VDS bottles were kept in 
the Shielded Cells and the analysis repeated one and two weeks later.

As can be seen from Table IX, the laboratary analysis for Slurry A $(2.2 \mathrm{~g} / \mathrm{kg})$ was reasonably accurate both days. The average $(2.0 \mathrm{~g} / \mathrm{kg})$ was within one standard deviation $(0.3$ $\mathrm{g} / \mathrm{kg}$, or 158$)$ of the expected value $(2.2 \mathrm{~g} / \mathrm{kg})$. . For Slurry $B$ $(10.8 \mathrm{~g} / \mathrm{kg})$, the first day's results were biased low by 508 , . averaging $5.2 \mathrm{~g} / \mathrm{kg}$ with a standard deviation of $1.2 \mathrm{~g} / \mathrm{kg}$ (238). The next day the results were excellent, with the average $(10.6 \mathrm{~g} / \mathrm{kg})$ well within one standard deviation $(0.5$ $\mathrm{g} / \mathrm{kg}$, or $5 \%)$ of the expected value $(10.8 \mathrm{~g} / \mathrm{kg})$. The reason for the poor result on the first day is not known, but suggests that the sample preparation method needs improvement.

The results of the analyses from the Shielded Cells sampies. are biased low. This is expected because the extra handling and sample preparation steps required for Shielded Cells samples provides more opportunities to lose benzene. Slurry A results were biased low by $67 \%$. (average $0.73 \mathrm{~g} / \mathrm{kg}$, standard deviation 38\%) and the Slurry B results were biased low by 738 (average $2.9 \mathrm{~g} / \mathrm{kg}$, standard deviation 318 ). The bias in the Shielded Cells method (compared to the laboratory method) indicates that about $64-65 \%$ of the benzene is lost through the extra steps.

The data suggests that the rate of loss of benzere from the VDS bottle is not very large (at these benzene concentrations). This result should be verified if improvements to the method significantly reduce the random error and bias.

The large bias in the test results suggest that the actual benzene concentration in the tank samples was three times higher than the values shown in Table VIII. This is not unreasonable. The samples were taken from an unstirred tank. without stirring, the solids will either settle or rise to the surface and become more concentrated than if they were distributed evenly in tank. Since the benzene tends to associate with the solids, it will also become concentrated. Therefore, if a tank sample is taken from the zone containing the solids, the benzene concentration would be expected to be high relative to the tank average. Based on observations of small samples, concentrating by a factor of 3 through gravity settling is not unreasonable. This bias could be corrected if the average solids content of the tank is known and the solids content of the sample is measured. However, if the benzene is not evenly distributed in the solids then this correction may not be accurate either.

If the ability to accurately measure benzene concentrations in slurries. is required, then the following actions are recommended. The first recommendation is applicable to 
laboratory simulant measurements; the second to both laboratory and tank measurements, and the remainder are applicable to waste tank measurements.

- Improve the reliability of the benzene measurements in the laboratory. -Optimize sample size, container size, and method of stirring to promote benzene evaporation from the viscous slurry.

- Determine the benzene distribution in unstirred slurries in and the relationship to the solids content.

-Results of a benzene distribution study may place a limit on the potential accuracy of the method.

- Determine the loss of benzene during VDS sampling operations.

-Operation of the VDS sampler requires pouring slurry from the sampler into the vDS bottle. This allows evaporation of benzene. The magnitude of this loss needs to be measured.

- Decrease benzene losses from samples generated in the Shielded Cells.

-The probable reasons for the low bias for Shielded Cells samples are the extra handling steps and time required to remove sample from the cell and then analyze in a radiohood.

\section{salt Solution Density}

Salt solution density correlates well with the total salt. concentration. Measuring the density is an easy and rapid method to estimate the sodium concentration in the tank. The relationship between salt concentration and solution density was reported previously for simulated waste solutions. ${ }^{7}$ Equations relating density to total sodium ion concentration were obtained for three anion.distributions (average, high-nitrate, and high-hydroxide anion distributions). These equations are not accurate for the very high hydroxide composition in Tank $48 \mathrm{H}$. Therefore, a new correlation was obtained based on the approximate Tank 48H composition shown in Table $x$. The simulant solution was prepared from reagent grade chemicals, weighed to accuracies better than 18, and diluted in volumetric glassware accurate to $< \pm 1 \%$ err. Portions of the initial $5.2 \mathrm{M} \mathrm{Na}$ solution were measured by weight and diluted in volumetric glassware to obtain the two dilutions at 2.7 and 1.52 molar $\mathrm{Na}^{+}$. The density of the dilutions and the correlation are shown in Table XI. With the correlation, the sodium concentration can be estimated from a density measurement quickly, and possibly more accurately, than by routine analytical methods. This method of estimating sodium concentration should be used 
TABLE X. Tank 48E Simulant Composition

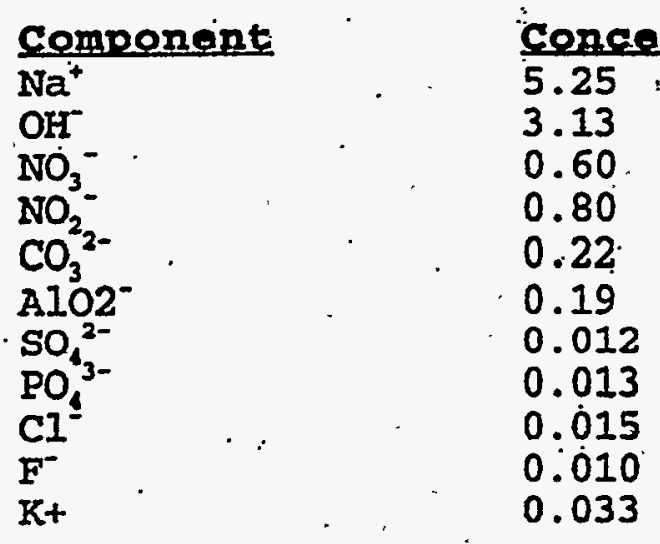

TABLE XI.: Density of Tank $48 \mathrm{Bg}$ simulant at $23^{\circ} \mathrm{C}$

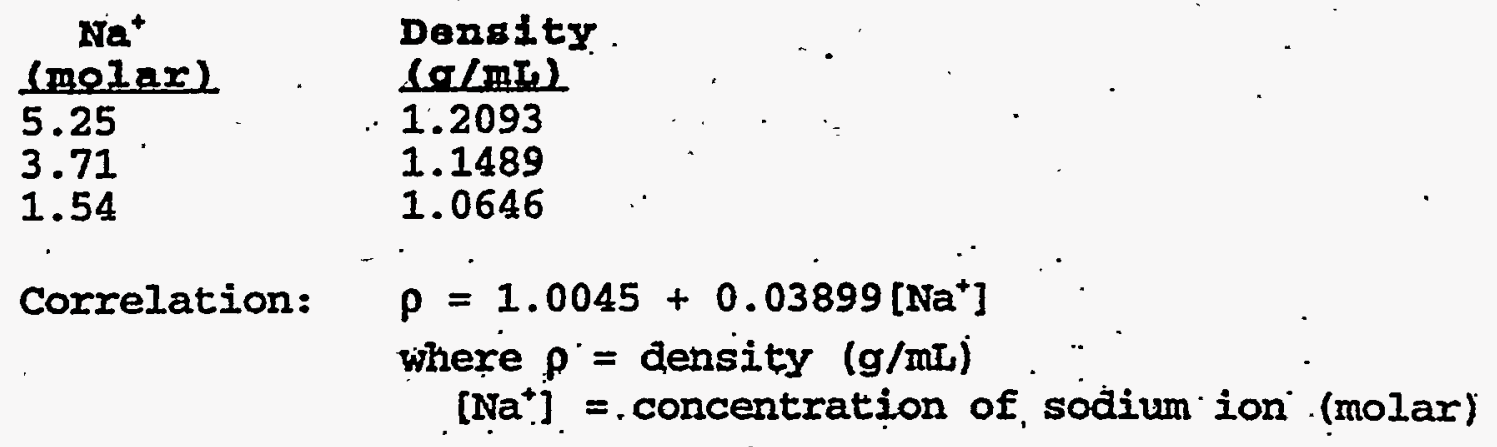

TABLE XII. Comparison of Predicted and Measuired sodium Concentrations in Tank $48 \mathrm{BH}$ Solutions

pote somple, pensity

$6 / 95$

$10 / 7 / 95$

$10 / 12 / 95$

$12 / 1 / 95$ ITP-208 $1: 160$

$6 / 28 / 96$ ITP-311

ITP-312

ITP-313
(a/mL) .

1.207

1.203

1.204

$1: 202$

1.197

$1.201 \pm .003$

1.140

$\because$
Na* (molar). Rredicted Measured*
5.19
$5.04 \pm .59$

* Measured by atomic absorption or emission spectroscopy. . **Based on samples taken prior to addition of NaTPB. See Réference 5 .

tThe three bottles were combined and a.portion analyzed. 
cautiously since changes in the anion distribution will change the density relationship. Table XII lists Tank $48 \mathrm{H}$ densities and measured sodium concentrations and compares them to predicted: sodium concentrations. Inspection of the resuits shows that the equation agrees well with most of the measured values. The measured $\mathrm{Na}^{+}$value for the October 1995 sample $(4.01 \mathrm{M})$ is probably low, since most evidence

indicates that the initial batch concentration was 4.7 molar sodium. The previously reported high hydroxide correlation equation predicts $10 \%$ lower $\mathrm{Na}^{+}$concentrations.

The correlation of density to salt concentration suggests $a$. potential application of this measurement to test for inadvertent dilution of samples. During the PVT-1 tests; three VDS bottles were found to contain diluted samples; presumably caused by VDS sampler operation. ${ }^{2}$ Dilution was concluded from the results of several analyses, including phenol, nitrate, and nitrite. A measurement of density. would also have corroborated the other results, or could have been used as a quality assurance test of the sample prior to submission for the other analyses. A $20 \%$ dilution is easily detected by the density measurement.

Changes in C8-137 pith Time

During April and May 1996, two Tank 48H sample sets had Cs137 concentrations significantly higher than expected from recent trends in the tank. A graph of the data is shown in Figure 4. The results for ITP-278, ITP-279, ITP-285, and. ITP-286 are significantly above the line defined by the previous and subsequent samples. The samples were tested in several ways to determine the oxigin of the high values. The tests and Cs-137 results are listed in Table XIII and they indicate the following..

- The initial high values were real and reproducible.

- The Cs-137 values decreased with time. Expected values were achieved after $1-2$ weeks storage.

- The high values were not due to sample preparation or analytical variability..

The high Cs-137 concentrations were probably not due to contamination in the shielded Cells. Contamination in the Shielded Cells is typically less that $1 \mathrm{nCi} / \mathrm{g}$ as shown by the blank sample from August 30 (Table I) and subsequent blanks taken during the PVT-1 tests.

The high Cs-137 concentrations were not due to adulteration of the sample. Dilution with water could cause high Cs-137 by dissolving some of the precipitate. Additional characterization of the first samples showing high Cs-137 (ITP-278 and ITP-279) indicated no dilution had occurred. 


\section{TABLE XIII. Cs-137 Concentrations}

\begin{tabular}{|c|c|c|c|c|c|c|}
\hline$\ldots . . . . . . . . . . .4$ Action & & & Sample & 5 & & \\
\hline - & ITP-278 & ITP-279 & tTP-280 & ITP-287 & ITP-285 & ITP-286 \\
\hline Date removed from TK $48 \mathrm{H}$ & 13-Apr & 13-Apr & $13-$ Apr & $29-A p r$ & 4-May & A-May \\
\hline 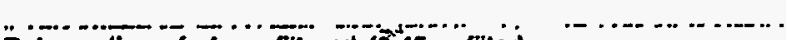 & & & & & & \\
\hline Dale portion of surry chlered $(0,45 \mu$ fiter) & 15-Ap? & 15-Apr & & 30-Apr & B+May & 8.May \\
\hline Cs-137 (ac)/g) inilial gamme scan. . : $\quad$ - ... & 308 & 380 & & 188 & 289 & 432 \\
\hline$\therefore$ rogeat scan on gams sample: & 308 & .379 & & & & \\
\hline$\ldots$ & & & $=$ & $\therefore$ & & \\
\hline Date portion of slurny fillered (duplicales or triplicales, $0.45 \mathrm{H}$ ) & 3+MaY & 3-May & 3+May & 3+hisy & 10-May & 10-May \\
\hline $\mathrm{Cs}-137$ (nC)/g) (after one pass through filter) & $181,181$. & 241,239 & $192,191,180$ & $184 ; 182$ & 230 & 286 \\
\hline ......... (after second pass through same filler) & & & & & 241 & 299 \\
\hline 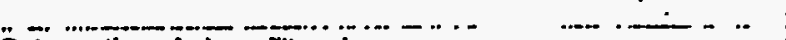 & & & & & $\cdot$ & \\
\hline Date portion of slumy tittered. & & & & & 14-May & 14-May \\
\hline Cs-137 (nCU/g) $0.45 \mu$ fller. & & & & & 203 & 250 \\
\hline $0.20 \mu$ fiter & & & & & 202 & 258 \\
\hline
\end{tabular}

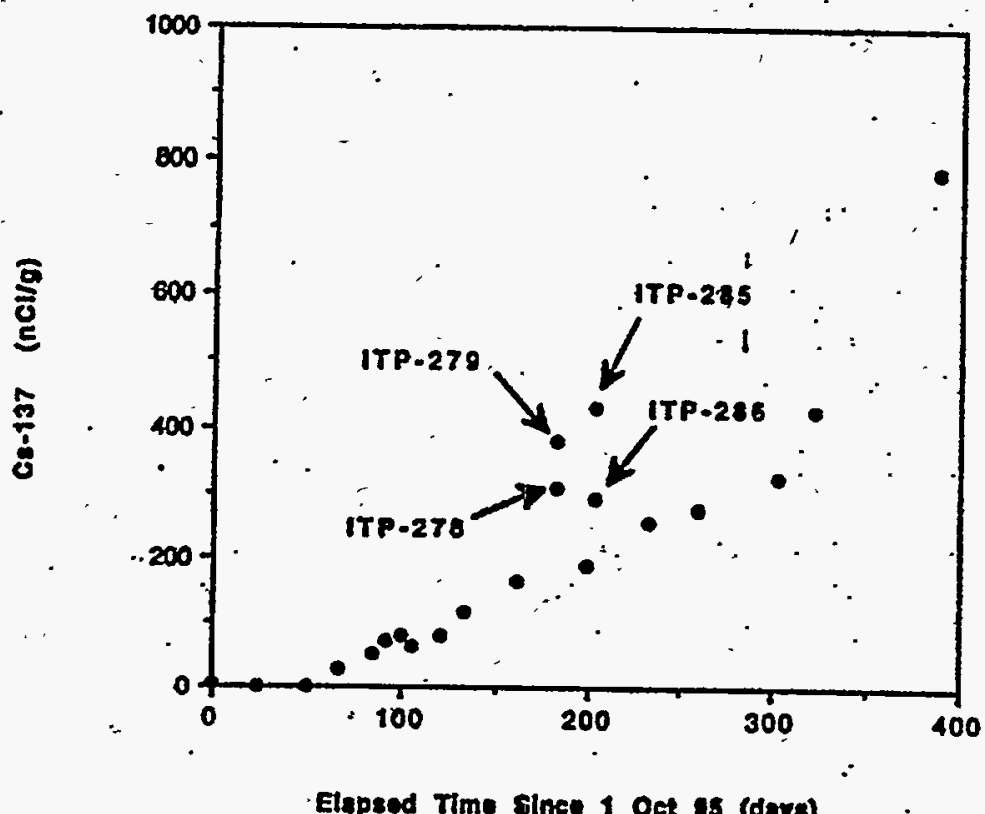


The high values were initially postulated to be linked to extended pump operation. Excessive pump operation may produce submicron-sized particles that cannot be removed by the 0.45 micron filters used for sample preparation. However, after examining foux sampling events, no clear correlation was found between high Cs-137 concentrations and pump operations. Subsequently the. Tank $48 \mathrm{H}$ sampling procedure was changed so that pumps were always run immediately prior to sampling but the high $\mathrm{Cs}-137$ values did not occur again. Attempts to improve filtration during sample preparation included passing the filtrate through the same filter a second time (the solids accumulated in the first pass could help filter finer particles during the second pass) and using a finer filter $(0.2$ micron instead of 0.45 micron pore size). Neither method decreased the Cs-137 concentration, but they were attempted on samples that were not far above the expected value.

This observation has not been adequately explained and cannot be further investigated with current tank samples since the phenomenon has not occurred again. If it occurs again, the following actions are recommended.

- Test finer filters (0.2 micron or smaller) on samples that are far above expected values:

- Test filtration with a cross-flow filter in the Shielded Cells to determine if the phenomenon will occur during plant operations.

If it is determined that this phenomenon could occuir in the ITP facility and impact plant operations; then additional actions can be planned.

\section{C8-137/Total Cosium Ratio In Tank 48z}

The ratio of Cs-137 to total cesium in Tank $48 \mathrm{H}$ is important in the evaluation of CsTPB solubility. Knowing the ratio, . one can calculate the total cesium concentration in the supernate from a. measurement of the Cs-137 gamma activity. The ratio of total cesium to $\mathrm{Cs}-137$ was obtained by a combination of gamma spectroscopy and ICP-MS measurements on a dissolved slurry sample. Aliquots (1 mL) of the Tank 48H sample taken August 30, 1997 (ITP-370) were digested in nitric or in nitric/hydrofluoric acid. and diluted with water. The results of the analyses are shown in Table XIV. The atom percentage of Cs-137 corresponds to waste with an average age of 35 years (assuming no $\mathrm{Cs}-133$ has been introduced), which is not unreasonable for the mix of waste in Tank $48 \mathrm{H}$. 


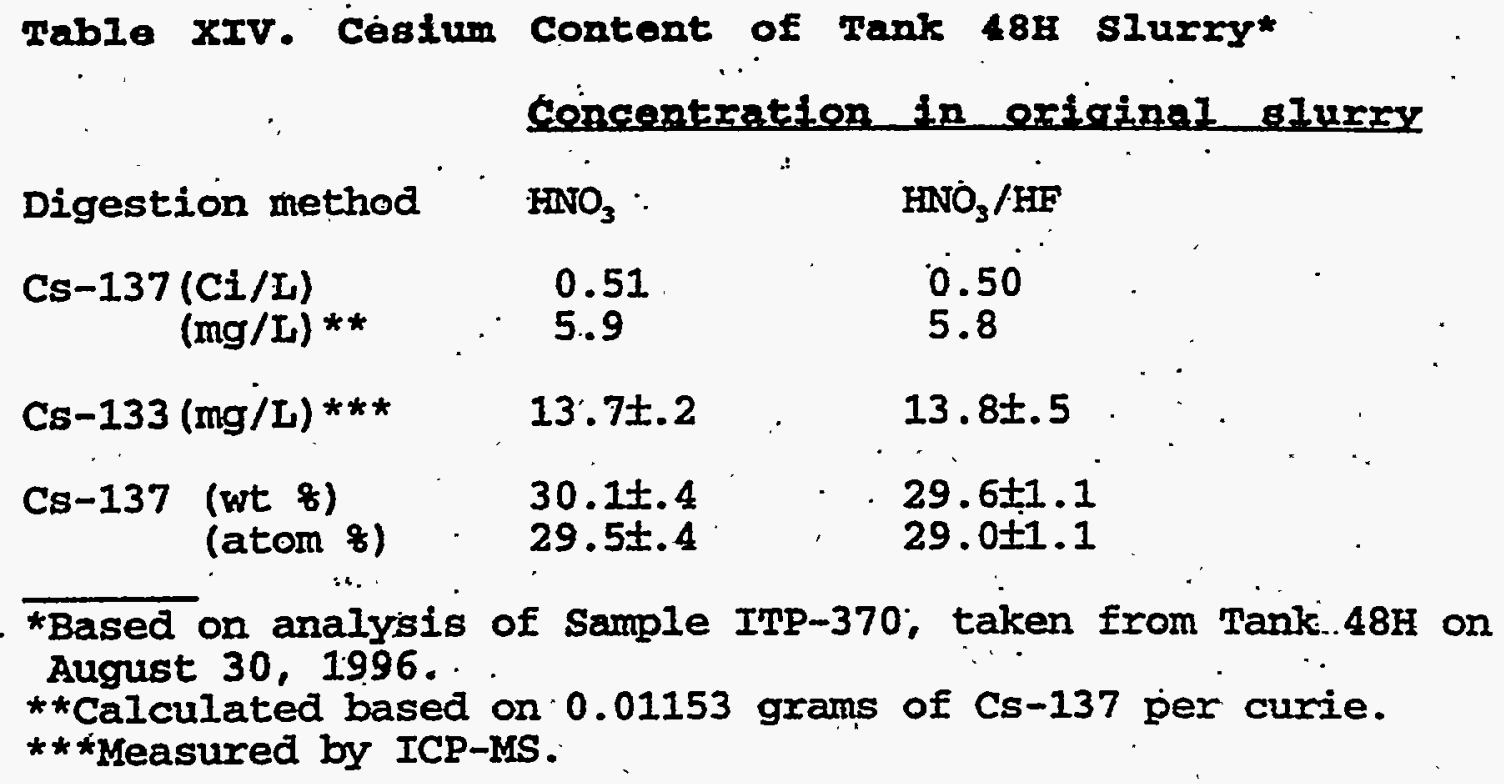

\section{CONCLUSIONS AND RECOMMENDATIONS}

The major composition changes in Tank $48 \mathrm{H}$ between April and August 1996 were a slow increase in the Cs-137 and potassium concentrations, and a slow decrease in the phenylboronic acid (1PB) concentration.

An investigation of the precision of sampling and analytical methods show that most routine methods are reproducible to 土11\%. A significant exception.is $1 P B$ which has a total. variability of $\pm 30 \%$, but half of this variability is due to a. downward trend in concentration over the duration of the . experiment. Several trends due to delays in analysis were detected, but they were small and did not significantly effect the results except for 1PB and nitrite. Changes. in sample composition during the time required for the free hydroxide.analysis. were identified and the problem was corrected.

The soluble copper concentration in Tank $48 \mathrm{~F}$ between August and November 1996 varied between $<.3$ to $1.6 \mathrm{mg} / \mathrm{L}$. Highly consistent results were obtained for samples analyzed on three occasions over a period of 15 months. The reason why. the concentration varied in the tank samples is unresolved.

Weight percentage solids. in Tank $48 \mathrm{H}$ averaged $2.30 \pm .36$ wt of in good agreement with an expected concentration of 2.7 wt 8 . There appears to be a $-15 \%$ low bias in the method which could be corrected by additional work.

Benzene measurements on tank samples prepared in the Shielded Cells facility are biased low by $70 \%$ so the current method 
predicts only the order of magnitude to the benzene concentration. Several means to improve the method are suggested.

The following are recommendations regarding the andytical methods.

- Routine analytical methods

- No changes are recommended for the routine analytical methods for $\mathrm{Cs}_{5}-137$, free hydroxide, nitrate, nitrite, boron, potassium, and phenol

- Phenylboronic acid

- No changes in the analytical method are recommended, but delays between sampling and analysis should be considéred since. detectable changes in the concentration can occur. over time. This recommendation also applies to measurements of tetraphenylborate, triphenylborane, and diphenylborinic acid.

- Copper

- Further improvements to the copper method are not recommended at this time. However, it is recomended that copper concentrations in Tank $48 \mathrm{H}$ and simulant tests be monitored.

- Insoluble solids

- The variability in this method can be reduced by. improvements to both the sampling and analytical methods. The potential use and required accuracy of the method need to be defined before attempting improvements.

- Benzene

-This method can be improved by optimizing the sample preparation method to promote benzene evaporation from the viscous slurry samples and by determining the benzene distribution on solids in unstirred sluries. These results are applicable to both laboratory simulant and Tank $48 \mathrm{H}$ samples.

-Tank $48 \mathrm{H}$ sample results can be improved by eliminating (or quantifying) benzene loses during VDS sampling operations and sample preparation steps used in the Shielded Cells. These steps are recommended after establishing an accuracy requirement for tank benzene measurements 


\section{QUATITY ASSURANCE}

The data in this report is recorded in the following technical notebooks WSRC-NB-95-.023 (D. D. Walker) and WSRC-NB-96-613 (D. D. Walker).

\section{RETERENCES}

1. D. D. Walker, M.' J. Barnes, C. I. Crawford; R. F. Swingle, R. A. Peterson, M: S. Hay, and S. D. Fink, "Decomposition of Tetraphenylborate in Tank 48H (U)," WSRCTR-96-0113, Rev.0, May, 10, 1996.

2. D. D. Walker. W. T. Boyce, C. J. Coleman, D. P. Diprete, A. A. Ekkechukwu, C. W. Hsu, S. F. Peterson, R. J. Ray, L. I. Tovo, M. J. Whitaker, and J. E. Young, "Analytical Results for Samples From Process Verification Test, Phase 1 (U), " WSRC-TR-97-0041, Rev.0; February 21, 1997.

3. M. S. Hay and T. B. Edwards, "Statistical Analysis of ESP. Verification Test Samples (U), "WSRC-RP-94-1224, November 4, 1994.

4. D. D. Walker and N. E. Bibler, "Radiolysis and Reactions of Nitrate and Nitrite Solutions for the Coupled In-Tank Precipitation and Late Wash Process (U), "WSRC-RP-94-798, August 19, 1994.

5. C. J. Coleman, T. B. Edwards, and C.·A. Nash, "Statistical. Analysis of Sample Data from Tank 48H (U)," WSRC-TR-95-0325; September 29, 1995.

6. Westinghouse Savannah River Company, "Process Requirements 241-82H Control Room (U) *, WSRC-IM-91-63, Rev.15, October 1996 .

7. D. D. Walker and C. J. Coleman;, "Densities and Weight Percentage Solids of Simulated Salt Solutions (U), "WSRC-TR91-176, April 17, 1991.

8. L. L. Tovo and W. T. Boyce, "Analysis of Copper in the In-Tank Precipitation Process Caustic Samples (U), "WSRC-TR96-0400, December 12, 1996. 


\section{APPESTIX A \\ Description of finalytical Methods}

\section{Cesium-137}

Cs-137 was measured by gamma spectroscopy counting methods using $3 \mathrm{mI}$ samples. A high-purity germanium gamma spectroscopy system operated through a Canberrra Genie PC software interface was used for the analysis. The method is described in Manual L16.1, Procedure \#ADS-2420.

\section{Organic Compounds in salt solution}

Phenylboronic acid (1PB) and phenol were measured by high performance liquid chromatography (HPIC) on a Hewlett Packard LC with a $2.1 \times 250 \mathrm{~mm}$ Dychrom Chemosorb 5-ODS-UH column using acetonitrile-water eluent. The HPLC instrument methods are described in Manual I16.1, Procedure \#ADS-2655. The methodology of sample preparation, standards, and standard preparation for. HPLC analyses is described in SRT-ADS-96-0438.

\section{Potassium and sodium}

Potassium and sodium ion concentrations were measured by flame atomic absorption using a Varian SpectrAA-400 spectrometer. Each sample is diluted 1:4 (sample:suppressant). in a suppressant solution of $2000 \mu \mathrm{g} / \mathrm{mL}$ cesium. For more concentrated samples, additional dilutions are made with 1600 $\mu \mathrm{g} / \mathrm{mL}$ cesium. The method is described in Manual LI6.1. Procedure \#ADS-1549.

\section{Boron and Aluminum}

Boron and aluminum concentrations were measured by Inductively Coupled Plasma Emission Spectroscopy (ICPES) using an ARL 3580 instrument.

\section{Coppex}

Copper concentrations were measured by Inductively Coupled plasma Emission Spectroscopy (ICPES) using an ARr 3580 instrument. Samples were diluted $10 \mathrm{X}$ and acidified to a pH less than or equal to 2 using 5 wt 8 nitric acid. Spiked. samples were analyzed with each sample to verify that there is no loss of copper. A $1000^{\circ} \mathrm{mg} / \mathrm{L}$ copper standard purchased from High Purity, Ine. was used to prepare the spikes. The method is described in Manual L16.1, Procedure \#ADS-1509 and in Reference 8.

Results from the ICPES method were verified by Inductively Coupled Plasma Mass Spectrometry. (ICPMS) using a Fisons PQ1 instrument. Samples were diluted $100 \mathrm{X}$ and acidified to $\mathrm{pH} \leq 2$ using 0.6 wt \& nitric acid. Spiked samples were analyzed with each sample as verification that there is no 
loss of copper. A $1000 \mathrm{mg} / \mathrm{L}$ copper purchased from High purity. Inc. was used to prepare the spikes. The method is described. in Manual, L16.1, Procedure *ADS-1551 and in Reference 8 .

\section{Nitrate and Nitrite Ion}

Nitrate and nitrite concentrations were determined using ion chromatography. Samples were diluted.to within 1.inear calibration range $(1-40 \mathrm{ppm})$ and eluted from a low capacity ion exchange resin column (AG4A/AS4A, Dionex) using carbonate/bicarbonate eluent. The instrument used.

was a Dionex Series 2000 Advanced Chromatography system with isocratic elution and conductivity detection. The method is described in Manual L16.1, Procedure *ADS-2306.

\section{Free Hydroxide and Carbonate}

Free hydroxide was measured by titration with $0.1 \mathrm{~N}$ HCl using a Radiometer VIT90 Autotitiation System. The sample was first saturated with strontium chloride to precipitate the carbonate. The hydroxide was then measured by titration to an endpoint of $\mathrm{pH} 4$. The method is described in Manual L16.1, Procedure \#ADS-2256.

\section{Height Percentage solids}

Weight percentage solids were measured by gravimetric methods in the Shielded.Cells. A slurry sample $(5-10 \mathrm{~g})$ was filtered through a preweighed filter paper (Whatman, fiberglass, 0.45 micron, $5.5 \mathrm{~cm}$ diameter), the solids washed with three $5 \mathrm{~mL}$ portions of water, and the filter paper dried to constant ${ }^{*}$ weight at $100{ }^{\circ} \mathrm{C}$.

\section{Benzene}

In the shielded Cells, a 1-mL aliquot of slurry from a VDS bottle was placed into a capped flask ( $50 \mathrm{mi}$ internal volume) and stirred to allow the benzene to evaporate. A $0.200 \mathrm{mr}$ sample of the vapor space was removed through a septum using a locking syringe. The syringe was.iocked (closed). removed from the shielded Cells, and taken to a radiohood. The syringe contents were emptied into a septum vial ( 60 mL internal volume).. Samples from the septum vial were. injected into a gas chromatograph to measure the benzene concentration. The instrument was an finU Model 301 gas chromatograph with $10.2 \mathrm{eV}$ photoionization detector and $1 / 8$ inch $\times 3$ ft long column packed with 3 wt of $\$$ p-2100 on Chromosorb $120 / 140$ ( Whatman, Co.). The gas chromatograph was calibrated daily with standards obtained from scott Specialty Gases. The methods used are described in Manual I12.1, Procedure ITP-006, Rev.3 12/20/94 (calibration) and Procedure ITP-OP-005, Rev.3, 12/20/94 (operation). 


\section{APPENDIX $B$ \\ Statistical Analysis of Tank 48 E Variability study}

\section{OVERVIEW OF TANK 48H DATA}

Samples of Tank 48H slurry have been taken and analyzed. Three dip bottles were taken. on the following dates as indicated:

\begin{tabular}{|llc|}
\hline Sample ID & Date & Coded ID \\
ITP-356 & $8 / 05 / 96$ & A \\
ITP-359 & $8 / 10 / 96$ & B \\
ITP-361 & $8 / 11 / 96$ & C \\
\hline
\end{tabular}

Over time, each of these three samples was subsampled on three occasions, denote these as Day 0, Day 6 and Day 12. Two subsamples were taken on each of these three occasions for each of the three samples. Measurements were made for several analytes on each of these subsamples. The resulting data for the analytes of interest are presented in Table 1.

\begin{tabular}{|c|c|c|c|c|c|c|c|c|c|c|c|}
\hline $\begin{array}{c}\text { Sample } \\
\text { B } \\
\mathbf{A} \\
\mathbf{B} \\
\mathbf{C} \\
\mathbf{A} \\
\mathbf{C} \\
\mathbf{B} \\
\mathbf{C} \\
\mathbf{C} \\
\mathbf{A} \\
\mathbf{B} \\
\mathbf{A} \\
\mathbf{C} \\
\mathbf{B} \\
\mathbf{A} \\
\mathbf{A} \\
\mathbf{B} \\
\mathbf{C}\end{array}$ & $\begin{array}{c}\text { Day } \\
0 \\
0 \\
0 \\
0 \\
0 \\
0 \\
6 \\
6 \\
6 \\
6 \\
6 \\
6 \\
12 \\
12 \\
12 \\
12 \\
12 \\
12\end{array}$ & $\begin{array}{c}\text { Sampling } \\
\text { Order } \\
1 \\
2 \\
3 \\
4 \\
5 \\
6 \\
1 \\
2 \\
3 \\
4 \\
5 \\
6 \\
1 \\
2 \\
3 \\
4 \\
5 \\
6 \\
\end{array}$ & $\begin{array}{c}\text { Analytical } \\
\text { Order } \\
3 \\
2 \\
6 \\
1 \\
1 \\
5 \\
4 \\
3 \\
3 \\
4 \\
6 \quad 1 \\
\therefore \quad 5 \\
5 \\
2 \\
5 \\
2 \\
1 \\
3 \\
4 \\
6 \\
6\end{array}$ & $\begin{array}{c}\text { Cs-137 } \\
\text { (nCi/mL) } \\
374 \\
.356 \\
369 \\
367 \\
355 \\
371 \\
371 \\
400 \\
397 \\
467 \\
399 \\
386 \\
391 \\
391 \\
392 \\
.301 \\
391 \\
391 \\
.385 \\
392 \\
\end{array}$ & $\begin{array}{c}\text { Free OH } \\
\text { (molar) } \\
1.40 \\
1.42 \\
1.20 \\
1.42 \\
1.29 \\
1.27 \\
1.52 \\
1.19 \\
1.12 \\
1.60 \\
1.39 \\
1.44 \\
1.31 \\
1.41 \\
1.56 \\
1.47 \\
1.31 \\
1.17 \\
\end{array}$ & $\begin{array}{c}\text { B } \\
\text { (molar) } \\
0.04561 \\
0.04117 \\
0.04302 \\
0.04033 \\
0.04246 \\
0.03996 \\
0.04283 \\
0.04006 \\
0.03987 \\
0.04311 \\
0.04246 \\
0.04181 \\
0.04098 \\
0.04533 \\
0.04274 \\
0.04283 \\
0.04385 \\
0.04228 \\
\end{array}$ & $\begin{array}{c}\text { Nitrate } \\
\text { (molar) } \\
0.42 \\
0.43 \\
0.43 \\
0.41 \\
0.43 \\
0.40 \\
0.41 \\
0.38 \\
0.39 \\
0.39 \\
.0 .41 \\
0.40 \\
0.42 \\
0.43 \\
0.44 \\
0.43 \\
0.43 \\
0.40 \\
\end{array}$ & 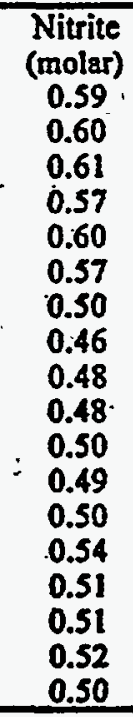 & $\begin{array}{c}\mathrm{K} \\
\text { (mmolar) } \\
0.1450 \\
0.1350 \\
0.1394 \\
0.1445 \\
0.1381 \\
0.1389 \\
0.1509 \\
0.1448 \\
0.1601 \\
0.1483 \\
0.1494 \\
0.1494 \\
0.1402 \\
0.1394 \\
0.1361 \\
0.1350 \\
0.1427 \\
0.1422 \\
\end{array}$ & $\begin{array}{c}\text { Phenol } \\
\text { (molar) } \\
0.01506 \\
0.01411 \\
0.01419 \\
0.01360 \\
0.01428 \\
0.01355 \\
0.01424 \\
0.01361 \\
0.01332 \\
0.01431 \\
0.01422 \\
0.01424 \\
0.01306 \\
0.01408 \\
0.01372 \\
0.01388 \\
0.01394 \\
0.01313\end{array}$ & $\begin{array}{c}1 \mathrm{~PB} \\
\text { (mmolar) } \\
1.157 \\
1.034 \\
1.148 \\
0.861 \\
1.132 \\
1.140 \\
0.681 \\
0.763 \\
0.829 \\
0.574 \\
0.599 \\
0.574 \\
0.648 \\
0.714 \\
0.714 \\
0.689 \\
0.755 \\
0.673 \\
\end{array}$ \\
\hline
\end{tabular}

\section{OBJECTIVE OF THE STATISTICAL ANALYSES}

The objective of these statistical analyses is to investigate the variation (and its sources) for the data of Table 1. The repeated measurements (over time) and replicate samples provide an opportunity for investigating a number of interesting questions. These questions and their answers are addressed in this appendix of the report.

What are the sources of significant variation in these results? To answer this question, the data for each analyte of Table 1 were analyzed against a random effects model: - Experiments conducted to diagnose sources of variability in a laboratory method or in a manufacturing process often use a random effects model. A factor such as time could influence an analyte's measurements in a fixed or random manner. Time would be considered a fixed factor for an analyte if there were a consistent (for each of the three samples) trend in the analyte's measurements over time. If the analyte's measurements 
varied over time; but in more of a random fashion, then time would be considered to have a random effect. For each analyte, the type of effect anticipated for a factor influences the assumptions and interpretation of the term for this factor in the statistical model for this analyte's measurements:

The random effects model for each analyte of interest is given by

$$
y_{i j k}=\mu+\alpha_{i}+\beta_{i j i}+\varepsilon_{k[i j]}
$$

where

$i=1,2$, and 3 (the sample index, corresponding to coded sample ID's A, B, and C),

$\mathrm{j}=1,2$, and 3 (the time index, corresponding to Day 0, Day 6, and Day 12),

$\mathrm{k}=1$ and 2 (the measurement index, corresponding to the two replicates),

$\mathrm{y}_{\mathrm{ijk}} \quad$ is the $\mathrm{k}^{\text {th }}$ measurement for the given analyte at time $\mathrm{j}$ on sample $i_{j}$

$\mu \quad$ is the true underlying analyte value for the tank,

$\alpha_{i}$ is the random effect-attributable to the $i^{\text {th }}$ sample,

$\beta(i)$ is the random effect attributable to the $\mathrm{j}^{\text {th }}$ time for the $\mathrm{i}^{\text {th }}$ sample, and

$\varepsilon_{\mathrm{k}[\hat{j}]} \cdot$ is the residual random effect (due to analytical/measurement errors) attributable with the $\mathrm{k}^{\text {th }}$ measurement at tinle $\mathrm{j}$ on sample $\mathrm{i}$.

For this model, each term present (except for $\mu$ ) is considered as a random variable (i.e., all of the factors are considered as random effects) with a zero mean and a constant variance. These random variables are assumed to be independent, and each is usually assumed to follow a normal probability distribution. Let the variances due to sample, time, and residual variation be denoted by $\sigma_{s}^{2}, \sigma_{t}^{2}$, and $\sigma^{2}$, respectively. The objective of this analysis is to estimate each of these sigmas which will lead to an understanding of the errors associated with estimating $\mu$. $\cdots \quad$ :

The statistical model given in (1). was estimated for each of the thirteen analytes using JMP@ [1]. Portions of the JMP output are:provided in Exhibits 1-7 at the end of this appendix.

This information has been summarized and expanded in Table 2 below. 
Table 2. Summary Information Derived from Random Effects Models for Analytes

\begin{tabular}{|c|c|c|c|c|c|}
\hline & & $\begin{array}{l}\text { Mean } \\
\text { Sum of }\end{array}$ & $\begin{array}{l}\text { Number } \\
\text { of }\end{array}$ & \multicolumn{2}{|c|}{$\begin{array}{l}95 \% \text { Confridence Interval } \\
\text { for the Mean }\end{array}$} \\
\hline Analyte & Mean & Squares & Obs. & Lower Limit & Upper Limit \\
\hline $\mathrm{Cs}-137(\mathrm{nCi} / \mathrm{mL})$ & 388 & 413.167 & 18 & 367.4 & 408.6 \\
\hline Free OH (molar) & $1.36 i$ & 0.07097 & 18 & 1.091 & 1.631 \\
\hline B (molar) & 0.04226 & 0.00002 & 18 & 0.038 & 0.047 \\
\hline Nitrate (molar) & 0.4139 & 0.00087 & 18 & 0.384 & 0.444 \\
\hline Nitrite (mölar) & 0.5294 & 0.00317 & 18 & 0.472 & 0.586 \\
\hline $\mathrm{K}$ (mmolar) & 0.143294 & 0.00004 & 18 & 0.137 & 0.150 \\
\hline Phenol (molar) & 0.013919 & 0.00000137 & 18 & 0.013 & 0.015 \\
\hline IPB (mmolar) & 0.815787 & 0.00476 & 18 & 0.746 & 0.886 \\
\hline
\end{tabular}

\begin{tabular}{|c|c|c|c|c|}
\hline \multirow{3}{*}{ Analyte } & \multicolumn{4}{|c|}{$\begin{array}{c}\text { Components of Variation } \\
\quad \text { Variance }\end{array}$} \\
\hline & - Sample & Day & Residual & Total \\
\hline & 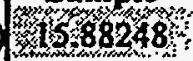 & 386.1325 & 317.8718 & 719.88678 \\
\hline Free OH (molar) & 0.009631 & 4300 & 0.013185 & 0.022816 \\
\hline B (molar) & 0.000003 & 3,31907 & $: 8.03 E-07$ & 0.00000412 \\
\hline Nitrate (molar) & 0.000136 & 0.000219 & 0.000057 & 0.000412 \\
\hline Nitrite (molar) & 0.000217 & 0.002939 & 0.000072 & 0.003228 \\
\hline K (mmolar) & 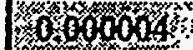 & 0.000037 & 0.000014 & 0.000055 \\
\hline Phenol (molar) & $2.201 \mathrm{E}-07$ & 5.795E-08 & $4.45 E-08$ & 3.2255E-07 \\
\hline IPB (mmolar) & 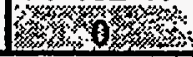 & 0.050511 & 0.00935 & 0.059861 \\
\hline
\end{tabular}

\begin{tabular}{|c|c|c|c|c|c|c|c|c|}
\hline \multirow[b]{2}{*}{$\begin{array}{l}\text { Analyáte } \\
-137 \text { (nCi/mL) }\end{array}$} & \multicolumn{4}{|c|}{$\begin{array}{c}\text { Components of Variation } \\
\% \text { of Total Variance. }\end{array}$} & \multicolumn{4}{|c|}{$\begin{array}{l}\text { Comporients of Variation } \\
\% \text { Relatfve Standard Deviation }\end{array}$} \\
\hline & Sample & Day & Residual & Total & Sample. & Day & Residual & Totai- \\
\hline Free OH (molar) & $42.2 \%$ & $\begin{array}{r}0.0 \% \\
\end{array}$ & $57.8 \%$ & $100 \%$ & $\begin{array}{l}1.0 \% \\
7.2 \%\end{array}$ & $\begin{array}{l}5.1 \% \\
0.0 \%\end{array}$ & $\begin{array}{l}4.6 \% \\
8.4 \%\end{array}$ & $\begin{array}{r}6.9 \% \\
11.1 \%\end{array}$ \\
\hline B (molar) & $72.8 \%$ & $7.7 \%$ & $19.5 \%$ & $.100 \%$ & $4.1 \%$ & $1.3 \%$ & $2.1 \%$ & $4.8 \%$ \\
\hline Nitrate (molar) & $33.0 \%$ & $.53 .2 \%$ & $13.8 \%$ & $100 \%$ & $2.8 \%$ & $3.6 \%$ & $1.8 \%$ & $4.9 \%$ \\
\hline Nitrite (molar) & $6.7 \%$ & $91.0 \%$ & $2.2 \%$ & $100 \%$ & $2.8 \%$ & $10.2 \%$ & $1.6 \%$ & $10.7 \%$ \\
\hline K (mmolar) & $7.3 \%$ & $67.3 \%$ & $25.5 \%$ & $100 \%$ & $1.4 \%$ & $4.2 \%$ & $2.6 \%$ & $5.2 \%$ \\
\hline Phenol (molar) & $68.2 \%$ & $18.0 \%$ & $13.8 \%$ & $100 \%$ & $3.4 \%$ & $1.7 \%$ & $1.5 \%$ & $4.1 \%$ \\
\hline IPB (mmolar) & $0.0 \%$ & $84.4 \%$ & $15.6 \%$ & $100 \%$ & $0.0 \%$ & $27.5 \%$ & $11.9 \%$ & $30.0 \%$ \\
\hline
\end{tabular}

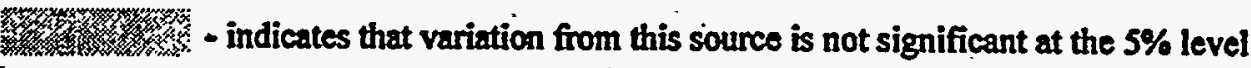

Specifically, a $95 \%$ confidence interval for the mean Tank $48 \mathrm{H}$ value of each analyte is computed as well as the components of variation of the data in Table 1. These components of variation are presented as (estimated) variances (the estimates of $\sigma_{s}^{2}, \sigma_{t}^{2}$, and $\sigma^{2}$ ) and as percent relative (to the mean) standard deviations. The variance from each source (sample, day and residual) is also expressed as a percentage of the total variance. Table 2 provides an opportunity for a number of insights into the analytical measurements from Tank 48H. First of all, sample to sample variation is statistically 
significant for five of the eight analytes. The largest \% relative standard (\%RSD) for the sample variation is that for Free OH which is $7.2 \%$-- all others have a \%RSD less than $4.1 \%$. Secondly, variation due to time (when it is considered as a random effect, denoted by the factor "Day"), is statistically significant for all analytes except Free $\mathrm{OH}$ and B. The three largest \%RSD's due to "Day" variation are 27.5\% (IPB), 10:2\% (Nitrite), and $5.1 \%$ (Cs-137). The \%RSD's due to time for the other analytes are all less than $4.2 \%$. Finally, the two largest \%RSD's for the residual variation (due to subsampling, preparation, and measurement) are $11.9 \%$ (1PB) and $8.4 \%$ (Free OH). The \% RSD's due to residual variation for the other analytes are all less than $4.6 \%$. Note that this residual variation is a measure of the reproducibility of the analytical derivations from a sample bottle.

Table 2 also shows the total variation and provides a breakdown of the total variance as a percentage contribution from each of the factors: sample; day, and residual. These variances are used to determine $95 \%$ confidence intervals for the mean value of each analyte for Tank $48 \mathrm{H}$. In decreasing sequence, the uncertainties of the analytes mean values, expressed as a $\pm \%$, are:

Relative Uncertainties in the Average Measurement at a 95\% Confidence Level

\begin{tabular}{|cccccccc|}
\hline $19.8 \%$ & $11.9 \%$ & $10.8 \%$ & $8.6 \%$ & $7.2 \%$ & $7.1 \%$ & $5.3 \%$ & $4.9 \%$ \\
Free OH & B & Nitrite & $1 \mathrm{~PB}$ & Nitrate & Phenol & Cs- 137 & $\mathrm{~K}$ \\
\hline
\end{tabular}

In the discussion above, the time factor (denoted by the variable "Day") was considered as a random factor; let's. now turn our attention to the question of possible systematic effects (specifically, trends) between time and these analytical measurements. Exhibits 519 provide analyses for time trends considering each of the three samples individually. There are no analytes for which a significant (at the $5 \%$ level) time trend is seen in these analyses.

In the analysis just discussed, each sample was investigated individually. At each point in time (i. e., Day 0,6, and 12), variations are introduced into the analytical and measurement procedures from a number of sources that may influence all (three samples and replicate) determinations on that day for a particular analyte. Orie such source is the calibration of the instrumentation. Variation from this source may cause the results for a given day to track higher or lower than the results from a previous or later day; thus, the data across the three samples may not be independent for any given day.

If this possibility is ignored and the data across the samples are assumed independent, a different model may be fitted. This model relates each analyte to two fixed-effect variables: sample and day. The results of fitting this model to the analyte measurements are presented in Exhibit 13-16 at the end of this appendix.

One or both of these effects are statistically significant at the $\mathbf{5 \%}$ level for the following analytes: 


\begin{tabular}{|lllll|}
\hline & & Sample Effect & & Day \\
Analyte & A & - B & C & Effect \\
Free OH (molar) & 0.065 & -.027 & -.038 & 0.0032 \\
B (molar) & -0.000468 & 0.001028 & -0.0005602 & ns \\
Nitrite (molar) & ns & ns & ns & -0.006 \\
Phenol (molar) & $-8.5 \mathrm{e}-6$ & $1.9 \mathrm{e}-4$ & $-1.8 \mathrm{e}-4$ & $-4.1 \mathrm{e}-5$ \\
IPB (mmolar) & ns & ns & ns & -0.032 \\
& & ns - indicates not significant at the 5\%-level \\
\hline
\end{tabular}

The significant "Day" effect for 1PB indicates that the concentration of this analyte may be decreasing over time. This may help explain the large variance from the "Day" component in Table 2 for 1PB. The root mean square error (RMSE) of 0.1495 mmolar for the 1PB analysis presented in Figure 16 provides an estimate of the random variation affecting the IPB measurements after accounting for this trend over time.

As a final point of interest, the analytical order in which the measurements were generated was investigated. Figure 17 at the end of this appendix provides a chart of the measurements for each analyte in analytical sequence. One point regarding these charts is worth mentioning. The Free $\mathrm{OH}$ (molar concentration) chart reveals a statistically significant decreasing sequence when plotted in analytical orter.

\section{References}

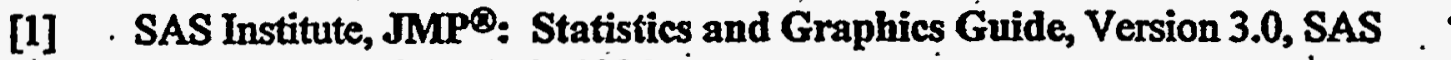
Institute, Inc., Cary, NC, 1994. 
- Exhibit 1. Random Effects Model Evaluation for Cs-137 and Free $\mathbf{O H}$ Cs-137 (nCi/mL)

\begin{tabular}{lr}
\multicolumn{2}{c}{ Summary of Fit } \\
RSquare & 0.595978 \\
Root Mean Square Ertor & 17.82896 \\
Mean of Response . & 388 \\
Observations (or Sum Wgts) & $\cdot 18$ \\
\hline
\end{tabular}

Lack of Fit

$\begin{array}{lrrrr}\text { Source } & \text { DF }: & \text { Sum of Squares } & \text { Mean Square } & \text { F Ratio } \\ \text { Lack of Fit } & 4 & 1456.3333 & 364.083 & 1.2245 \\ \text { Pure Error } & 9 & 2676.0000 & 297.333 & \text { Prob>F } \\ \text { Total Error } & 13 & 4132.3333 & & 0.3659\end{array}$

Variance Component Estimates

$\begin{array}{lr}\text { Component } & \text { Var Comp Est } \\ \text { Sample } & 15.88248 \\ \text { Day } & 386.1325 \\ \text { Residual } & \text {. . } 317.8718\end{array}$

Tests wrt Random Effects

$\begin{array}{lrrrrr}\text { Source } & \text { SS } & \text { MS Num } & \text { DF Num } & \text { F Ratio } & \text { Prob }>\text { F } \\ \text { Sample } & 826.333 & 413.167 & 2 & 1.2998 & 0.3058 \\ \text { Day } & 5269.33 & 2634.67 & 2 & 8.2885 & 0.0048\end{array}$

Free OH (molar)

$$
\begin{array}{lr}
\text { RSquare } & 9.464516 \\
\text { Root Mean Square Error } & 10.114826 \\
\text { Mean of Response } & 1.360556 \\
\text { Observations (or Sum Wgts) } & 18
\end{array}
$$

\section{Lack of Fit}

\section{Source}

Lack of Fit

Pure Enror.

Total Error

DF
9
13
Sum of Squares
0.08915556 .
0.08225000
0.17140556

Mean Square . F Ratió

$0.022289 \quad 2.4389$

0.009139. Prob $>$ F

Variance Component Estimates

Component
Sample
Day
Residual

Var Comp Est
0.009631
-0.00164
0.013185

Tests wrt Random Effects

$\begin{array}{lrrrrr}\text { Source } & \text { SS } & \text { MS Num } & \text { DF Num } & \text { F Ratio } & \text { Prob }>\text { F } \\ \text { Sample } & 0.14194 & 0.07097 & 2 & 5.3828 & 0.0198 \\ \text { Day } & 0.00674 & 0.00337 & 2 & 0.2558 & 0.7781\end{array}$




\section{Exhibit 2. Random Effects Model Evaluation for B and Nitrate}

B (molar)

\author{
RSquare \\ RSquare Adj' \\ Root Mean Square Exror \\ Mean of Response \\ Observations (or Sum Wgts)
}

0.782425

0.715479

0.000896

0.04226

. 18

Lack of Fit

\begin{tabular}{|c|c|c|c|}
\hline $\begin{array}{l}\text { Sotirce } \\
\text { Lack of Fit } \\
\text { Pure Error } \\
\text { Total Error }\end{array}$ & $\begin{array}{r}\text { DF } \\
4 \\
9 \\
13\end{array}$ & $\begin{array}{r}\text { Sum of Squares } \\
0.00000331 \\
\quad 0.00000712 \\
: \quad 0.00001044\end{array}$ & $\begin{array}{r}\text { Mean Square } \\
\cdot 8.287 e-7 \\
7.916 e-7\end{array}$ \\
\hline
\end{tabular}

Variạnce Component Estimates

\section{Component \\ Sample \\ Day \\ Residual}

Var Comp Est

0.000003

3.171e-7

$8.03 e-7$

Tests wrt Random Effects

$\begin{array}{lrrrrr}\text { Source } & \text { SS } & \text { MS Num } & \text { DF Num } & \text { F Ratio } & \text { Prob }>\text { F } \\ \text { Sample } & 0.00003 & -0.00002 & 2 & 20.0053 & 0.0001 \\ \text { Day } & 5.410-6 & 2.71 e-6 & 2 & 3.3694 & 0.0662\end{array}$

Nitrate (molar)

\section{Summary of Fit}

RSquare

Root Mean Square Error

Mean of Response

Observations (or Sum Wgts)
0.858667

19,85245

1309.889

\section{Lack of Fit}

Source

Lack of Fit

Pure Error

DF Sum of Squares

4

1008.5556

4115.0000

Total Error

.13

5123.5556 .
Mean Square
Var Comp Est : :
1949.434
513.2115
394.1197 252.139

457.222

F Ratio

0.5515

Prob $>$ F

$\because$

Variance Component Estimates

Componerit

Sample.

Day

Residual

Tests wrt Random Effects .

$\begin{array}{lrrrrrr}\text { Source } & \text { SS } & \text { MS Num } & \text { Dr Num } & \text { Ratio } & \text { Prob }>\text { F } \\ \text { Sample } & 24181.4 & 12090.7 & 2 & 30.6778 & 0.0000 \\ \text { Day } & 6946.78 & 3473.39 & 2 & 8.8130 & 0.0038\end{array}$


Exhibit 3. Random Effects Model Evaluation for Nitrite and $\mathrm{K}$

Nitrite (molar)

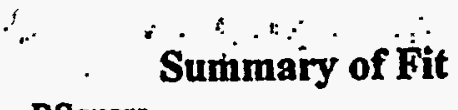

RSquare . :

Root Mean Square Error

Mean of Response

Observations (or Sum Wgts)
0.975984

0.008498

0.529444

18

\section{Lack of Fit}

\section{Source}

Lack of Fit

DF Sum of Squares

- Pure:Error

$4 \quad 0.00028889$

Total Error

$\therefore 90.00065000$

13

0.00093889

$$
\begin{aligned}
& \text { Mean Square - F Ratio } \\
& =0.000072 \quad 1.0000 \\
& 0.000072 \because \text { Prob }>\text { F }
\end{aligned}
$$

Variance Component Estimates

Componẹnt
Sample
Day
Residual

Var Comp Est

0.000217

0.002939

0.000072

Tests wrt Random Effects

$\begin{array}{llrrrrr} & \text { Source } & \text { SS } & \text { MS Num } & \text { DF Num } & \text { F Ratio } & \text { Prob }>\text { F } \\ & \text {.Sample } & 0.00274 & 0.00137 & 2 & 19.0000 & 0.0001 \\ \therefore \quad \text { Day } & 0.03541 & 0.01771 & 2.245 .1538 & 0.0000\end{array}$

K (mmolar)

$\begin{array}{rrr}\because & \text { Summary of Fit } \\ \text { RSquere } & \\ \text { RSquare Adj , } & 0.755807 \\ \text { i. Root Mean Square Error } & 0.680671 \\ \text { Mean of Response } & 0.003685 \\ \text { Observations (or Sum Wgts) } & 0.143294 \\ \end{array}$

Läck of fît

Source

Lack of Fit

Dir

DF Sum of Squares

Pure Error

9

Total Error

13.
0.00001257
0.00016395
0.00017652
Mean Square
0.000003
0.000018

F Ratio

0.1726

Prob $>$ F

0.9470

Variance Component Estimates

Component

Sample

Day

Residual
Var.Comp Est

0.000004

0.000037

0.000014

Tests wrt Ranḍom Effects

$\begin{array}{lrrrrr}\text { Source } & \text { SS } & \text { MS Num } & \text { DF Num } & \text { F Ratio } & \text { Prob }>\text { F } \\ \text { Sample } & 0.00008 & 0.00004 & 2 & 2.9676 & 0.0868 \\ \text { Day } & 0.00047 & 0.00023 & 2 & 17.1507 & 0.0002\end{array}$




\section{Exhibit 4. Rändöm Effects Model Evaluation for Phenol and 1PB}

Phenol (molar)

\begin{tabular}{lr}
\multicolumn{2}{c}{ Summary of Fit } \\
RSquare & 0.858667 \\
RSquare Adj & 0.815181 \\
Root Mean Square Error & 0.000211 \\
Mean of Response & 0.013919 \\
Observations (or Sum Wgts) & 18
\end{tabular}

Lack of Fit

Source

Lack of Fit

Pure Error

Total Error

DF
4
9
13

0.00000046

13.

$$
\begin{array}{r}
\text { Mean Square } \\
2.847 e-8 \\
5.162 e-8
\end{array}
$$

F Ratio

0.5515

Prob $>$ F

0.7032

\section{Variance Component. Estimates}

$\begin{array}{lr}\text { Component } & \text { Var Comp Est } \\ \text { Sample } & 2.201 \mathrm{e}-7 \\ \text { Day } & 5.795 \mathrm{e}-8 \\ \text { Residual } & 4.45 \mathrm{e}-8\end{array}$

Tests wrt Random Effects

$\begin{array}{lrrrrr}\text { Source } & \text { SS } & \text { MS Num } & \text { DF Num } & \text { F Ratio } & \text { Prob }>\text { F } \\ \text { Sample } & 2.73 e-6 & 1.37 e-6 & 2 & 30.6778 & <.0001 \\ \text { Day } & 7.84 e-7 & 3.92 e-7 & 2 & 8.8130 & 0.0038\end{array}$

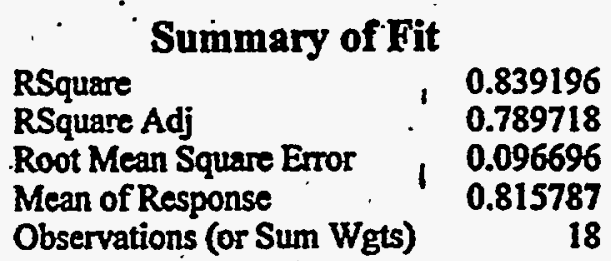

Lack of Fit

$\begin{array}{lrrrr}\text { Source } & \text { DF } & \text { Sum or Squares } & \text { Mean Square } & \text { F Ratio } \\ \text { Lack of Fit } & 4 & 0.07081089 & 0.017703 & 3.1399 \\ \text { Pure Error } & 9 & 0.05074157 & 0.005638 & \text { Prob }>\text { F } \\ \text { Total Error } & 13 & 0.12155246 & & 0.0711\end{array}$

Variance Component Estimates

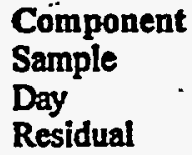

Tests wrt Random Effects

$\begin{array}{lrr}\text { Source } & \text { SS } & \text { MS Num } \\ \text { Sample } & 0.00952 & 0.00476 \\ \text { Day. } & 0.62483, & 0.31242\end{array}$

Var Comp Est
-0.00077
0.050511
0.00935

$\begin{array}{rrr}\text { DF Num } & \text { F Ratio } & \text { Prob }>\text { F } \\ 2 & 0.5090 & 0.6126 \\ 2 & 33.4129 & <.0001\end{array}$




\section{Exhibit 5. Time Effects for Cs-137 Across the Three Samples}

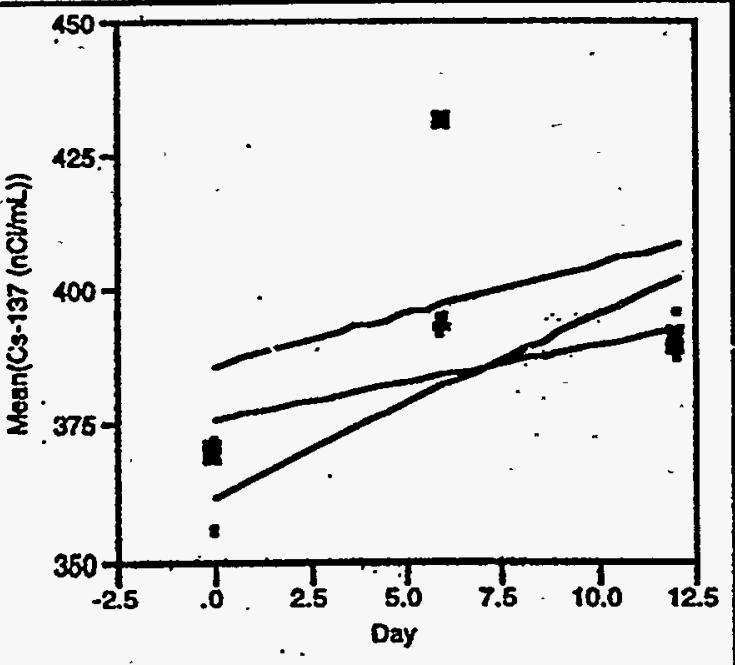

Linear Fit Sample=A:

$\operatorname{Mean}(\mathrm{Cs}-137(\mathrm{nCi} / \mathrm{mL}))=361.917+3.375$ Day

\section{Summary of Fit}

RSquare

Root Mean Square Error

Mean of Response

Observations (or Sum Wgts)
0.768507

15.71756

382.1667

Parameter Bstimates

$\begin{array}{lrrrr}\text { Term } & \text { Estimate } & \text { Std Error } & \text { t Ratio } & \text { Prob>it| } \\ \text { Intercept } & 361.91667 & 14.3481 & .25 .22 & 0.0252 \\ \text { Day } & 3.375 & 1.852332 & -1.82 & 0.3196\end{array}$

Linear Fit Sample-B: Summaryof Fit.

Porrmatir. Bstimates

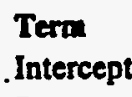

Day

Linear Fit Sumple-C: Summary of Fit

Parameter Estimates
$\operatorname{Mean}\left(C_{s} \cdot 137 \cdot(n C i / m \psi)\right)=375.833+1.41667$ Day

$$
\begin{array}{lrr}
\text { RSquare } & 0.561892 \\
\text { Root Mean Square Error } & 10.61446 \\
\text { Mean of Response } & \ldots 384.3333 \\
\text { Observations (or Sum Wgts) } & \cdot r
\end{array}
$$

\begin{tabular}{|c|c|c|c|c|}
\hline Term & Estimate & Std Error. & t Ratio & Probs $|t|$ \\
\hline Intercept & $\mathbf{3 7 5 . 8 3 3 3 3}$ & 9.689628 & 38.79 & 0.0164 \\
\hline Day & $: 1.4166667$ & 1.250926 & 1.13 & 0.4605 \\
\hline
\end{tabular}

$\operatorname{Mean}(C s-137(n C i / m L))=386.25+1.875$ Day

\section{RSquare}

Root Mean Square Error

Mean of Response:

Observations (or Sum Wgts)
0.124172

42.2537

397.5

3
Term
Intercept
Day

$\begin{array}{rr}\text { Estimate } & \text { Std Error } \\ 386.25 & .38 .57217 \\ 1.875 & 4.979646\end{array}$

$\begin{array}{rr}\text { t Ratio } & \text { Prub>|t] } \\ 10.01 & 0.0634 \\ 0.38 & 0.7707\end{array}$




\section{Exhibit 6. Time Effects for Free OHAcross the Three Samples}

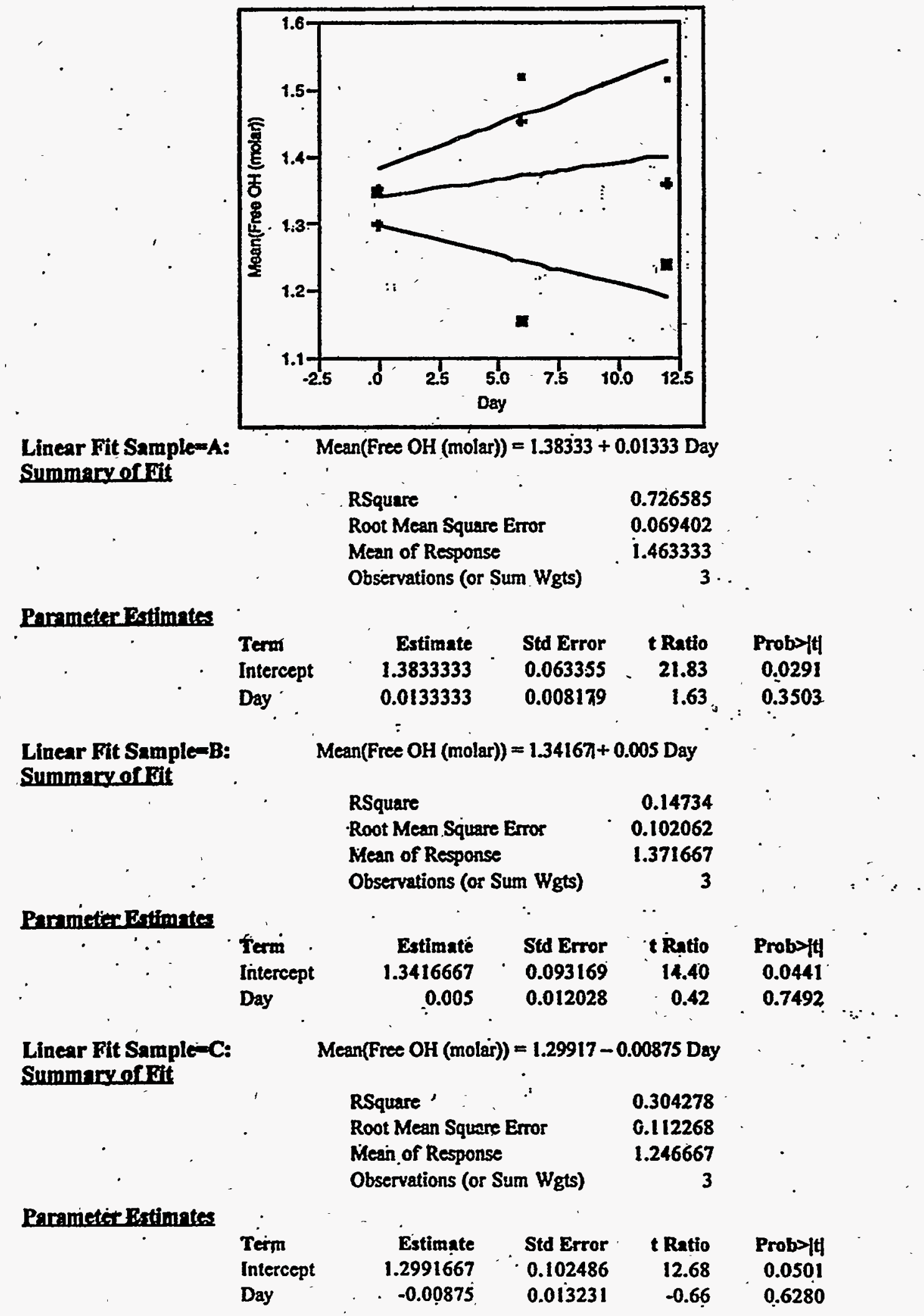


Exhibit 7. Time Effects for B Across the Three Samples

\section{Summary of Fit}

Linear Fit Samplex=A:

Term
Intercept
Day

Linear Fit Sample-B: Summary offit

Parameter Estimates

\section{Parameter Estimates}

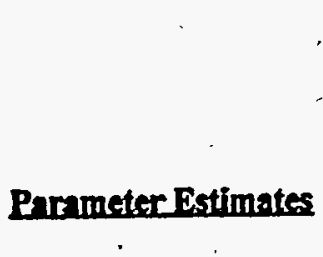

RSquare

Root Mean Square Error

Mean of Response

Observations (or Sum Wgts)
0.964286

0.000132

0.042353 Linear Fit Sample=C:
Summary of Bit:

$$
\therefore \text { Day }
$$

$\begin{array}{rrr}\text { Estimate } & \text { Std Error } & \text { t Ratio } \\ -0.0418671 & .0 .000121 & .346 .97 \\ \mathbf{0 . 0 0 0 0 8 0 9} & 0.000016 & 5.20\end{array}$
Prob>1t .
0.0018
0.1210


Exhibit 8. Time Effects for Nitrate Across the Three Samples

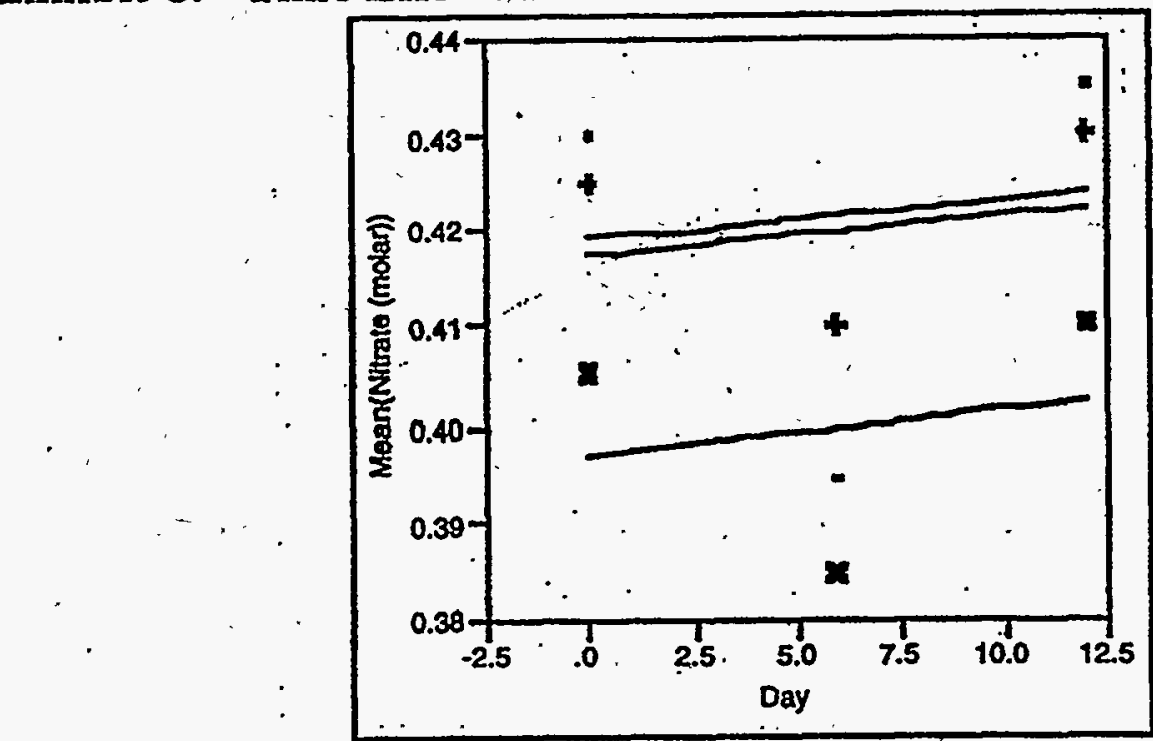

Linear Fit Sample=A: ${ }^{\prime} \cdot \quad$ Mean(Nitrate $($ molar $\left.)\right)=0.4175+0.00042$ Day

Summory of Fit

$$
\begin{array}{lr}
\text { RSquare } & 0.013158 \\
\text { Root Mean Square Error . } & 0.030619 \\
\text { Mean of Response } & 0.42 \\
\text { Observations (or Sum Wgts) } & 3
\end{array}
$$

Porameter Estimntes

$\begin{array}{lrrrr}\text { Term } & \text { Estimate } & \text { Std Error } & t \text { Ratio } & \text { Prob>-[t] } \\ \text { Intercept } & 0.4175 & 0.027951 & 14.94 & 0.0426 \\ \text { Day } & 0.0004167 & 0.0036 \varphi 8 & 0.12 & 0.9268\end{array}$

Linear Fit Sample-B: Summary of Fit

Linear Fit Sample=C: Summary of Fit

\section{Parameter Estimntes:}

Mean(Nitrate (molar) $)=0.41917 \not 0.00042$ Day

RSquare

Root Mean Square Error

Mean of $\dot{\text { Response }}$

Observations (or Sum Wgts)
0.057692

\begin{tabular}{|c|c|c|c|c|c|}
\hline & . & RSquare & & 0.035714 & \\
\hline & & Root Mean Squa & irror & 0.018371 & \\
\hline & & Mean of Respon & $\therefore \quad \therefore$ & 0.4 & - \\
\hline & & Observations (or & m Wgts) & 3 & \\
\hline arnmeter Estimnter: & & & & & \\
\hline$\because$ & Term & Estimate & Std Error & t Rutio & Probstt \\
\hline & Intercept & 0.3975 & 0.016771 & 23.70 & 0.0268 \\
\hline & Day: & 0.0004167 & 0.002165 & 0.19 & 0.8790 \\
\hline
\end{tabular}

0.014289

0.421667

. 3 


\section{Exhibit 9. Time Effects for Nitrite Across the Three Samples}

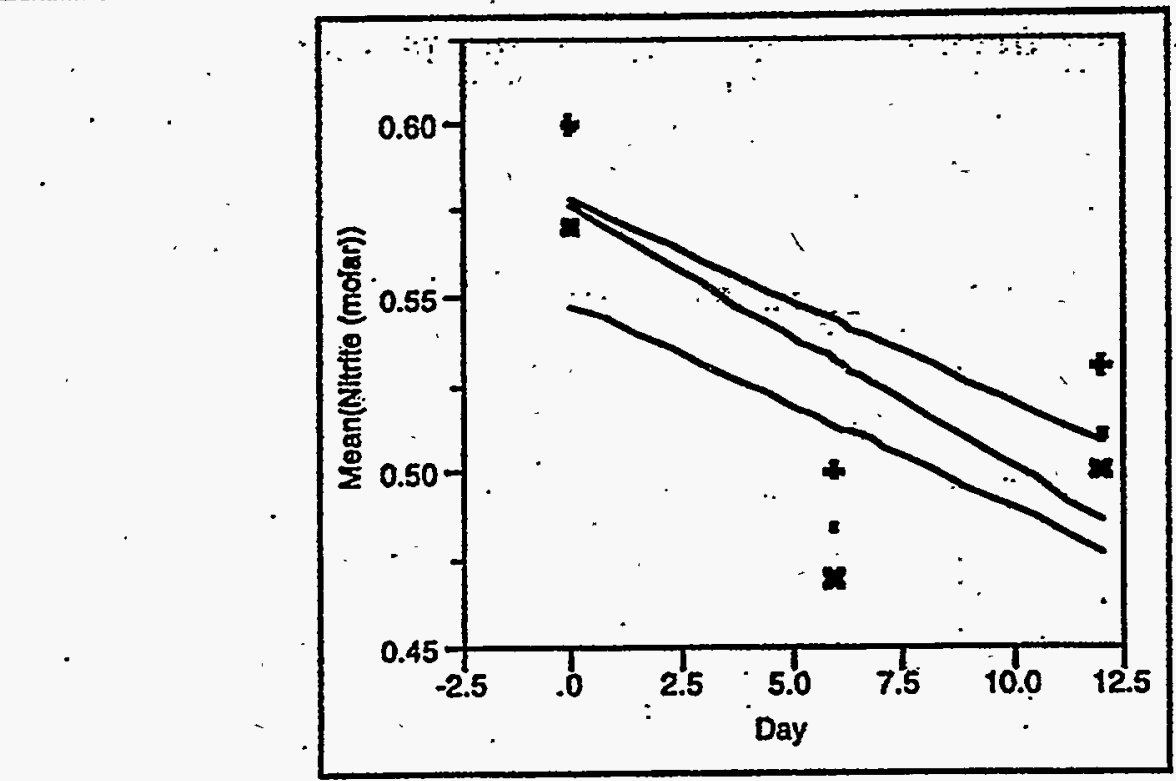

Linear Bit Sample*A: Summary of Fit
Mean(Nitrite (molar)) $=0.57667-0.0075$ Day.

\section{.RSquare}

0.553531

Root Mean Square Error

0.057155

Mean of Response

0.531667

3

\section{Parameter Estimntes}

Term
Intercept
Day

Linear Fit Sample-B: Summary of Fit.

$$
\text { Mean(Nitrite }(\text { molar }))=0.57833 \Gamma^{0.00583 . ~ D a y ~}
$$$$
\text { Std Error }
$$$$
0.052175
$$$$
\text { t Ratio }
$$$$
11.05
$$

$$
\begin{aligned}
& \text { RSquare } \\
& \text { Root Mean Square Error } \\
& \text { Mean of Response } \\
& \text { Observations (or Sum Wigts) }
\end{aligned}
$$

\subsection{9}

0.053072

C.543333

Barnmeter Estimntes

\begin{tabular}{lrrrr} 
Term & Estimate & Std Error & t Ratio & \multicolumn{1}{c}{ Prob>it } \\
Intercept & $0.5783333^{\circ}$ & 0.048448 & 11.94 & 0.0532 \\
Day & -0.005833 & 0.006255 & -0.93 & 0.5222
\end{tabular}

Linear Fit SamplecC: Summary of Fit

Mean(Nitrite $($ molar)) $=0.54833-0.00583$ Day

RSquare

Root Mean Square Error

Mean of Response .

Observations (or Sum W.gts)
0.46519

0.053072

0.513333 3.

Pammeter Estimates

$\begin{array}{lrr}\text { Term } & \text { Estimate } & \text { Std Error } \\ \text { Intercept } & 0.5483333 & \mathbf{0 . 0 4 8 4 4 8} \\ \text { Day } & -0.005833 & 0.006255\end{array}$

t Ratio

11.32

Rrob>yt|

0.0561

$\begin{array}{ll}-0.93 & 0.5222\end{array}$ 


\section{Exhibit 10. Time Effects for $K$ Across the Three Samples}

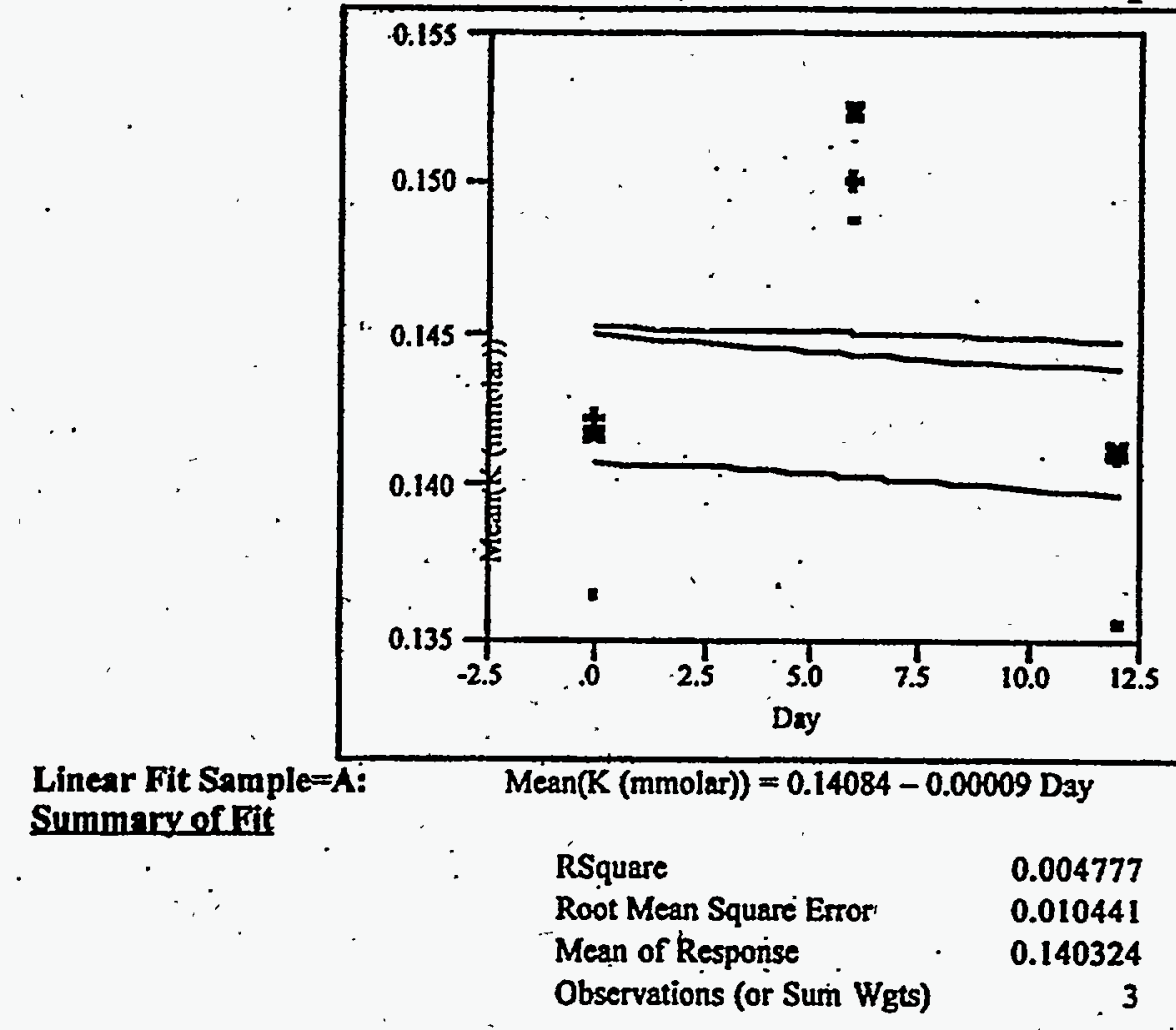

Parnmeter Eotimntes

$\begin{array}{lrrrr}\text { Term } & \text { Estimate } & \text { Std Error } & \text { i Ratio } & \text { Prob>it } \\ \text { Intercept } & 0.1408355 & 0.009531 & 14.78 & 0.0430 \\ \text { Day } & -0.000085 & 0.00123 & -0.07 & 0.9560\end{array}$

Linear Fit Sample-B: $\quad \cdot \operatorname{Mean}(K($ mmolar $))=0: 14503-0,0001$ Day Summary of Fit

$$
\begin{array}{lr}
\text { RSquare } & 0.0 i 3551 \\
\text { Root Mean Square Frror } & 0.006943 \\
\text { Mean of Response } & 0.144459 \\
\text { Observations (or Sum Wgts) } & 3
\end{array}
$$

\section{Barnmeter Estimates}

$\begin{array}{lrrrr}\text { Term } & \text { Estimate } & \text { Std Error } & \text { t Ratio } & \text { Prob }>14 \\ \text { Intercept } & 0.1450341 & 0.006338 & 22.88 & 0.0278 \\ \text { Day } & -0.000096 & 0.000818 & -0.12 & 0.9257\end{array}$

Linear Fit Sampleac: Summary of Fit

Rarameter Rstimntes

$$
\operatorname{Meän}(K(\text { mmolar }))=0.14535-0.00004 \text { Day }
$$

$\begin{array}{lr}\text { RSquare } & 0.00162 \\ \text { Root Mean Square Enror } & 0.008979 \\ \text { Mean of Response } & 0.145098 \\ \text { Observations (or Sum Wgts) } & 3\end{array}$

Estiminte
0.1453538
-0.000043

Std Error 0.008197 0.001058

$\begin{array}{cc}\text { Ratio } & \text { Prob>it| } \\ 17.73 & 0.0359 \\ -0.04 & 0.9744\end{array}$


Exhibit 11. Time Effects for Phenol Across the Three Samples

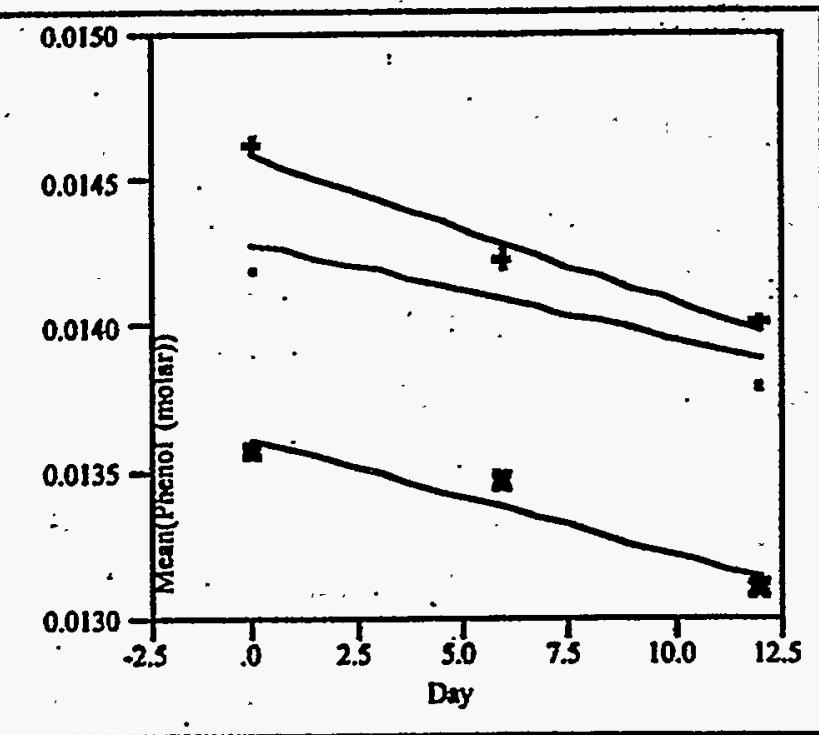

Linear Fit SamplexA: Summary of Fit

\section{Parameter Estimates}

$\begin{array}{lrrrr}\text { Term } & \text { Estimate } & \text { Std Error } & \text { t Ratio } & \text { Prob }>1 t \\ \text { Intercept } & 0.0142891 & 0.000208 & 68.73 & 0.0093 \\ \text { Day } & -0.000033 & 0.000027 & -1.24 & 0.4328\end{array}$

Linear Fit Sample=B: Summary of Fit

Bammeter Estimates

Linear Fit Sample $=\mathrm{C}$ : Summary of Eit

\section{Parameter Estimates}
RSquare
0.604839
Root Mean Square Enror
0.000228
Mean of Response
0.01409
Observationis (ör Sum Wgts)

3

\begin{tabular}{|c|c|c|c|c|c|}
\hline . & , & $\begin{array}{l}\text { RSquare } \\
\text { Root Mean Squa } \\
\text { Mean of Respon } \\
\text { Observations (or }\end{array}$ & nor & $\begin{array}{r}0.906716 \\
0.000108 \\
0.01338 \\
\quad 3\end{array}$ & \\
\hline Parameter Estimates & & & & & \\
\hline . & $\begin{array}{l}\text { Term } \\
\text { Intercept } \\
\text { Day }\end{array}$ & $\begin{array}{r}\text { Estimate } \\
0.0136188 \\
-0.00004\end{array}$ & $\begin{array}{l}\text { Std Error } \\
0.000099 \\
0.000013\end{array}$ & $\begin{array}{c}\text { t Ratio. } \\
137.56 \\
-3.12\end{array}$ & $\begin{array}{r}\text { Prob>ft] } \\
0.0046 \\
0.1976\end{array}$ \\
\hline
\end{tabular}


Exhibit 12. Time Effects for 1PB Across the Three Samples

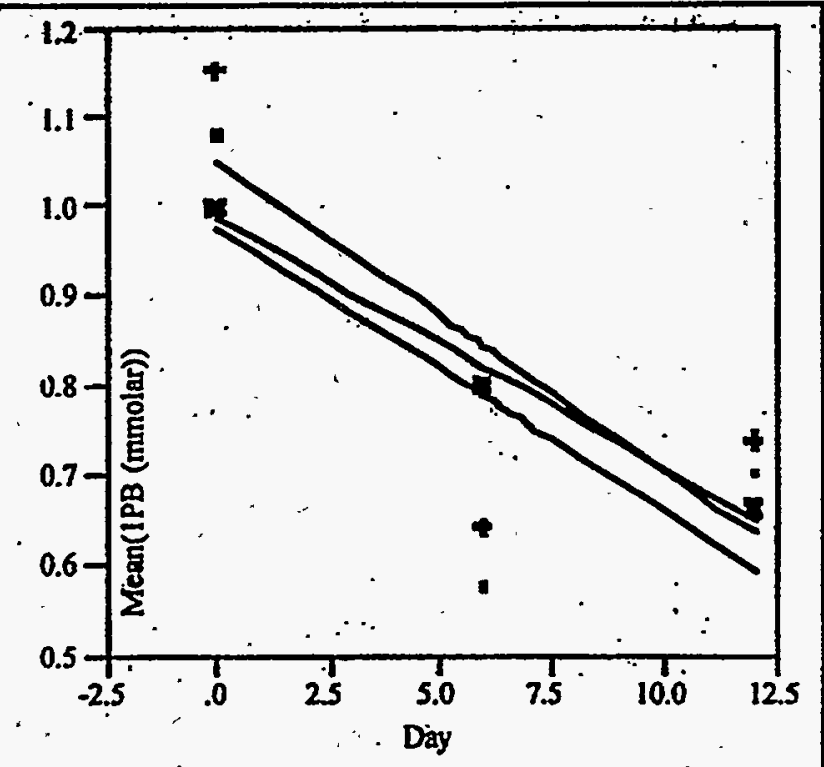

Linear'Fit Sample=A:Summary of Fit

Panmeter Extimates
- RS qqúuare

Root Mean Square Etror - Mean of Response

Observations (or Sum. Wgts)
0.519231

0.259551

0.786164

3 Term
Intercept
Day

$\begin{array}{cc}\text { Estimate } & \text { Std Error } \\ 0.9768936 & 0.236936 \\ -0.031788 & 0.030588\end{array}$

t Ratio

4.12

Prob> $\mid$ t $\mid$

$\dot{M} \operatorname{ean}(1 \mathrm{~PB}$ (mmolar) $)=1.05141$ L $0.03486 \mathrm{Day}$

Linear Fit Sample $=$ B: Summary of Fit

Parameter Extimates

$$
\begin{aligned}
& \text { RSquare } \\
& \text { Root Mean Square Error } \\
& \text { Mean of Response } \\
& \text { Observations (or Sum Wgts) }
\end{aligned}
$$
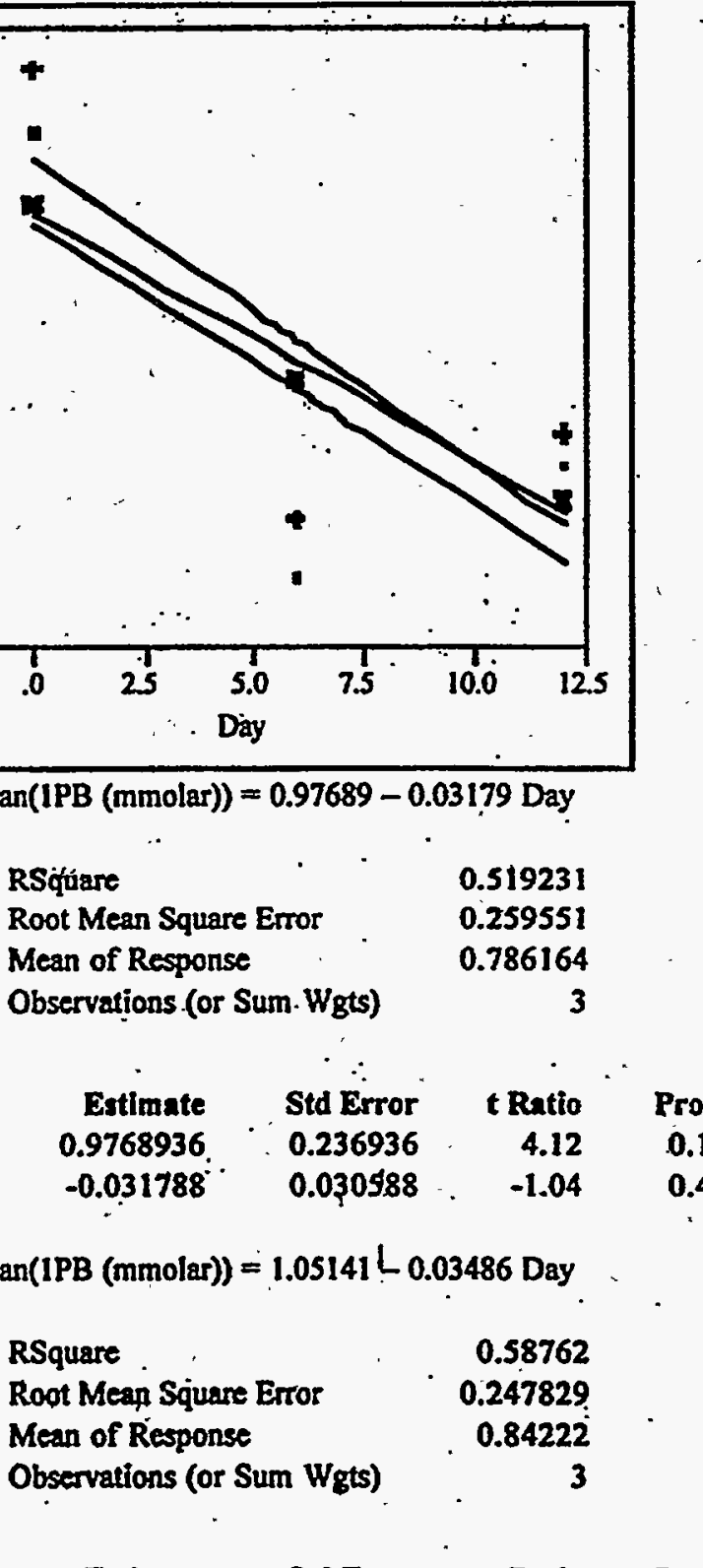

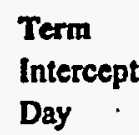
Intercept
Day

Estimate
1.0514083:
-0.034865
Std Error 0.226236
0.029207

$t$ Ratio

4.65

Prob>-1t

-1.19 .

0.1349

0.4439

Linear Fit Sample-C: Summary of Fit

\section{Parameter Estimates}

$\begin{array}{lrrrr}\text { Term } & \text { Estimate } & \text { Std Error } & \text { i Ratio } & \text { Prob>|t| } \\ \text { Ilntercept } & \mathbf{0 . 9 8 9 1 9 8 8} & 0.025987 & 38.07 & 0.0167 \\ \text { Day } & -0.02837 & 0.003355 & -8.46 & 0.0749\end{array}$




\section{Exhibit 13. Sample and Time Effects for Cs-137 and Free $\mathrm{OH}$}

Tank 48 Samples(Analyte $=$ Cs-137 (nCi/mL)) Summary of Fit

$\begin{array}{lr}\text { RSquare } & 0.289369 \\ \text { Root Mean Square Error } & 22.78523 \\ \text { Mean of Response } & 388 \\ \text { Observations (or Sum Wgts) } & 18\end{array}$

Lack of Fit

\begin{tabular}{|c|c|c|c|c|}
\hline Source & DF & Sum of Squares & Mean Square & F Ratio \\
\hline Lack of Fit & 5 & 4592.3333 & 918.467 & 3.085 \\
\hline Pure Error & 9 & 2676.0000 & 297.333 & Prob $>F$ \\
\hline Total Error & 14 & 7268.3333 & & 0.0675 \\
\hline
\end{tabular}

Parameter Estimates

$\begin{array}{lrlrr}\text { Term } & \text { Estimate } & \text { Std Error } & \text { t Ratio } & \text { Prob }>\mid 1 t] \\ \text { Intercept } & 374.66667 & 8.491554 & 44.12 & <.0001 \\ \text { Sample[A-C] } & -5.833333 & 7.595076 & -0.77 & 0.4552 \\ \text { Sample[B-C] } & -3.666667 & 7.595076 & -0.48 & 0.6367 \\ \text { Day } & \mathbf{2 . 2 2 2 2 2 2 2} & 1.096255 & 2.03 & 0.0621\end{array}$

Erfect Test

$\begin{array}{lrrrrrr}\text { Source } & \text { Nparm } & \text { DF } & \text { Sum of Squares } & \text { F Ratio } & \text { Prob }>F \\ \text { Sample } & 2 & 2 & \cdots & 826.3333 & 0.7958 & 0.4706 \\ \text { Day } & 1 & 1 & & 2133.3333 & 4.1091 & 0.0621\end{array}$

Tank 48 Samples(Analyte=Free OH (molar))

RSquare .

Root Mean Square Error

Mean of Response

Observations (or Sum Wgts)'
Summary of Fit

0.457217

0.111401

1.360556

18

Lack of Fit

$\begin{array}{lrrr}\text { Source } & \text { D } & \text { Sum of Squares } \\ \text { Lack of Fit } & 5 & 0.09149167 \\ \text { Pure Error } & 9 & 0.08225000 \\ \text { Total Error } & 14 & . & 0.17374167\end{array}$

F Ratio 2.0022

Prob $>$ F

0.1723

Parameter Estimates

$\begin{array}{lrrrr}\text { Term } & \text { Estimate } & \text { Std Error } & \text { t Ratio } & \text { Prob }>1 \text { 1] } \\ \text { Intercept } & 1.3413889 & 0.041517 & 32.31 & <.0001 \\ \text { Sample[A-C] } & 0.1027778 & 0.037134 & 2.77 & -0.0151 \\ \text { Sample[B-C] } & 0.0111111 & 0.037134 & 0.30 & 0.7692 \\ \text { Days. } & 0.0031944 & 0.00536 & 0.60 & 0.5607\end{array}$

Effect Test

$\begin{array}{lrr}\text { Source } & \text { Nparm. } & \text { DF } \\ \text { Sample } & 2 & 2 \\ \text { Day } & 1 & 1\end{array}$
Sum of Squares
0.14194444
0.00440833

FRatio Prob $>$ F

$5.7189 \quad 0.0153$

0.35352

0.5607 


\section{Exhibit 14. Sample and Time Effects for $B$ and Nitrate \\ Tank 48 Samples(Analyte=B (molar)) Summary of Fit

$\begin{array}{lr}\text { RSquare } & 0.72138 \\ \text { Root Mean Square Error } & 0.000977 \\ \text { Mean of Response } & 0.04226 \\ \text { Observations (or Sum Wgts) } & 18\end{array}$

Lack of Fit

$\begin{array}{lrrrr}\text { Source } & \text { DF } & \text { Sum of Squares } & \text { Mean Square } & \text { F Ratio } \\ \text { Lack of Fit } & 5 & 0.00000624 & 0.000001 & 1.5775 \\ \text { Pure Error } & 9 & 0.00000712 & 7.916 \mathrm{e}-7 & \text { Prob>F } \\ \text { Total Error } & 14 & 0.00001337 & & 0.2600\end{array}$

Parameter Estimates

\begin{tabular}{|c|c|c|c|c|}
\hline $\begin{array}{l}\text { Term. } \\
\text { Intercept }\end{array}$ & $\begin{array}{l}\text { Estimate } \\
0.0418054\end{array}$ & $\begin{array}{l}\text { Std Error } \\
0.000364\end{array}$ & $\begin{array}{l}\text { t Ratio } \\
\text { 114.80 }\end{array}$ & $\begin{array}{l}\text { Prob>>14] } \\
<.0001\end{array}$ \\
\hline Sample $[A=C]$ & 0.0000925 & 0.000326 & 0.28 & 0.7806 \\
\hline Sample[B-C] & 0.001588 & 0.000326 & 4.88 & 0.0002 \\
\hline Day & 0.0000758 & 0.000047 & 1.61 & 0.1292 \\
\hline
\end{tabular}

Efrect Tést

$\begin{array}{lrrrrrrr}\text { Source } & \text { Nparm } & \text { DF } & \text { Sum of Squares } & \text { F Ratio } & \text { Prob }>\text { F } \\ \text { Sample } & 2 & 2 & 0.00003213 & 16.8239 & 0.0002 \\ \text { Day } & . & 1 & 1 & 0.00000248 & 2.5998 & 0.1292\end{array}$

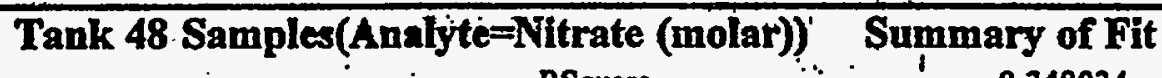

RSquare

Root Mean Square Error , $\quad 0.015603$

Mean of Response . 0.413889

Observations (or Sum Wgts) $\quad 18$

\section{Lack of Fit}

$\begin{array}{lrrrrr}\text { Source } & \text { DR } & \text { Sum of Squares } & \text { Mean Square } & \text { F Ratio } \\ \text { Luck of Fit } & 5 & & 0.00295833 & 0.000592 & 11.8333 \\ \text { Pure Error } & 9 & 0.00045000 & 0.000050 & \text { Prob>F } \\ \text { Total Error } & 14 & & 0.00340833 & & 0.0010\end{array}$

\section{Parameter Estimates}

\begin{tabular}{|c|c|c|c|c|c|}
\hline$\because \cdot \quad \therefore$ & Term & Estimate & Std Error & t Ratio & Prob> $|t|$ \\
\hline 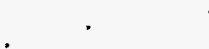 & Intercept & 0.4113889 & 0.005815 & .70 .75 & $<.0001$ \\
\hline & Sumple $[\mathrm{A}-\mathrm{C}]$ & 0.0061111 & .0 .005201 & 1.17 & 0.2596 \\
\hline & Sample[B-C] & 0.0077778 & 0.005201 & 1.50 & 0.1570 \\
\hline & Day $\quad \cdot$ & 0.0004167 & $0.00075 k$ & 0.56 & 0.5876 \\
\hline
\end{tabular}

Efrect Test

$\begin{array}{lrrrrr}\text { Source } & \text { Nparm } & \text { DF } & \text { Sum of Squares } & \text { F Ratio } & \text { Prob>F } \\ \text { Sample } & 2 & 2 & 0.00174444 & 3.5827 & 0.0554 \\ \text { Dayj } & 1 & 1 & 0.00007500 & 0.3081 & 0.5876\end{array}$


Exhibit 15. Sample and Time Effects for Nitrite and $\mathbf{K}$.

Tank 48 Samples(Analyte=Nitrite (molar)) Summary of Fit .

$\begin{array}{lr}\text { RSquare } & 0.521245 \\ \text { Root Mean Square Error } & 0.036564 \\ \text { Mean of Response } & 0.529444 \\ \text { Observations (or Sum Wgts) } & 18\end{array}$

Lack of Fit

$\begin{array}{lrrrr}\text { Source } & \text { DF } & \text { Sum of Squares } & \text { Mean Square } & \text { F Ratio } \\ \text { Lack of Fit } & 5 & 0.01806667 & 0.003613 & 50.0308 \\ \text { Pure Entor } & 9 & 0.00065000 & 0.000072 & \text { Prob }>\text { F } \\ \text { Total Error } & 14 & 0.01871667 & & <.0001\end{array}$

Parameter Estimates

$\begin{array}{lrrrr}\text { Term } & \text { Estimate } & \text { Std Erior } & \text { Ratio } & \text { Prob>|t] } \\ \text { Intercept } & 0.5677778 & 0.013626 & 41.67 & <.0001 \\ \text { Sample[A-C] } & 0.0022222 & 0.012188 & 0.18 & 0.8579 \\ \text { Sample[B-C] } & 0.0138889 & 0.012188 & 1.14 & 0.2736 \\ \text { Day } & -0.006389 & 0.001759 & -3.63 & 0.0027\end{array}$

Errect Test

$\begin{array}{lrrrrrr}\text { Source } & \text { Nparm } & \text { DF } & \text { Sum of Squares } & \text { F Ratio } & \text { Prob }>\text { F } \\ \text { Sample } & \cdot 2 & 2 & & 0.00274444 & 1.0264 & 0.3837 \\ \text { Day } & 1 & 1 & & 0.01763333 & 13.1897 & 0.0027\end{array}$

Tank 48 Samplea(Analyte=K (mmolar)) Summary of Fit

$\begin{array}{lrr}\text { RSquaré } & \text { I } & 0.1114812 \\ \text { Root Mean Square Error } & 0.006761 \\ \text { Mean of Response } & 0.143294 \\ \text { Observations (or Sum Wgts) } & 18\end{array}$

Lack of Fit

$\begin{array}{lrrrrrr}\text { Source } & \text { DF } & \text { Sum of Squares } & \text { Mean Square } & \text { F Ratio } \\ \text { Lack of Fit } & 5 & . & 0.00047594 & . & 0.000095 & 5.2253 \\ \text { Pure Error } & .9 & & 0.00016395 & & 0.000018 & \text { Prob }>\text { F } \\ \text { Total Error } & 14 & & 0.00063989 & & & 0.0159\end{array}$

Parameter Estimates

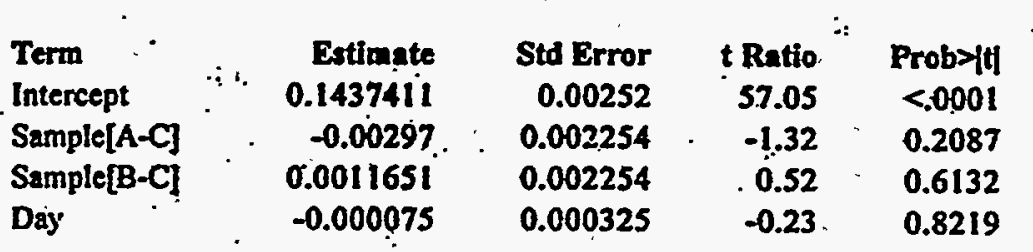

Effect Test

$\begin{array}{lrr}\text { Source } & \text { Nparm } & \text { DP } \\ \text { Sample } & \mathbf{2}^{-.2} & \mathbf{2} \\ \text { Day } & 1 & 1\end{array}$


Exhibit 16. Sample and Time Effects for Phenol and 1PB

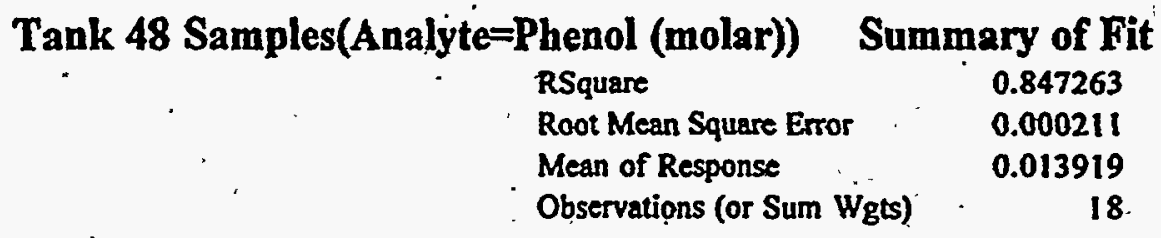

Lack of Fit

$\begin{array}{lrrrr}\text { Soiurce } & \text { Df } & \text { Sum of Squares } & \text { Mean Square } & \text { F Ratio } \\ \text { Lack of Fit } & 5 & 0.00000016 & 3.211 \text { e-8 } & 0.6220 \\ \text { Pure Error } & 9 & 0.00000046 & 5.162 e-8 & \text { Prob>F } \\ \text { Total Error } & 14 & 0.00000063 & & 0.6875\end{array}$

Parameter Estimates

$\begin{array}{lrrrr}\text { Term } & \text { Estimate } & \text { Std Error } & \text { t Ratio } & \text { Prob>it] } \\ \text { Intercept } & 0.0141666 & 0.000079 & 179.89 & <.0001 \\ \text { Sample[A-C] } & 0.0001712 & 0.00007 & 2.43 & 0.0291 \\ \text { Sumple[B-C] } & 0.0003678 & 0.00007 & 5.22 & 0.0001 \\ \text { Day } & -0.000041 & 0.00001 & -4.06 & 0.0012\end{array}$

Efrect Test

$\begin{array}{lrrrrrr}\text { Source. } & \text { Nparm } & \text { DF } & & \text { Sum of Squares } & \text { F Ratio } & \text { Prob }>\text { F } \\ \text { Sample } & 2 & 2 & & 0.00000273 & 30.5707 & <.0001 \\ \text { Day } & 1 & 1 & & 0.00000074 & 16.5192 & 0.0012\end{array}$

Tank 48 Samples(Analyte=1PB (mmolar)) Summary of Fit

$\begin{array}{lrr}\text { RSquare } & \quad 0.585961 \\ \text { Root Mean Square Error } \quad & 0.149517 \\ \text { Mean of Response } & 0.815787 \\ \text { Observations (or Sum Wgts) } & 18\end{array}$

Lack of Fit

\begin{tabular}{|c|c|c|c|c|}
\hline Source & DF & Sum of Squares & Mean Square & FRatio \\
\hline Lack of Fit & 5 & 0.26223210 & 0.052446 & 9.3024 \\
\hline Pure Enror & 9 & 0.05074157 & 0.005638 & Prob $>E$ \\
\hline Total Error & 14 & 0.31297367 & , & 0.0023 \\
\hline
\end{tabular}

Parameter Estimates

$\begin{array}{lrlrr}\text { Term } & \text { Estimate } & \text { Std Error } & \text { t Ratio } & \text { Prob>id } \\ \text { Intercept } & 1.0058336 & 0.055722 & 18.05 & <.0001 \\ \text { Sample[A-C] } & -0.029624 & 0.049839 & -0.59 & 0.5617 \\ \text { Sample[B-C] } & 0.0264333 & 0.049839 & 0.53 & -0.6042 \\ \text { Dés. } & -0.031674 & 0.007194 & -4.40 & 0.0006\end{array}$

Errect Test

$\begin{array}{lrrrrrr}\text { Source } & \text { Nparm } & \text { DF } & \text { Sum of Syuares } & \text { F Ratio } & \text { Prob }>\text { F } \\ \text { Sample } & 2 & 2 & 0.00951872 & 0.2129 & 0.8108 \\ \text { Day } & 1 & 1 & 0.43341200 & 19.3875 & 0.0006\end{array}$




\section{Exhibit 17. Analyte Measurements in Analytical Sequence}

Cs-137 (nCi/mL) By Anialytical Order

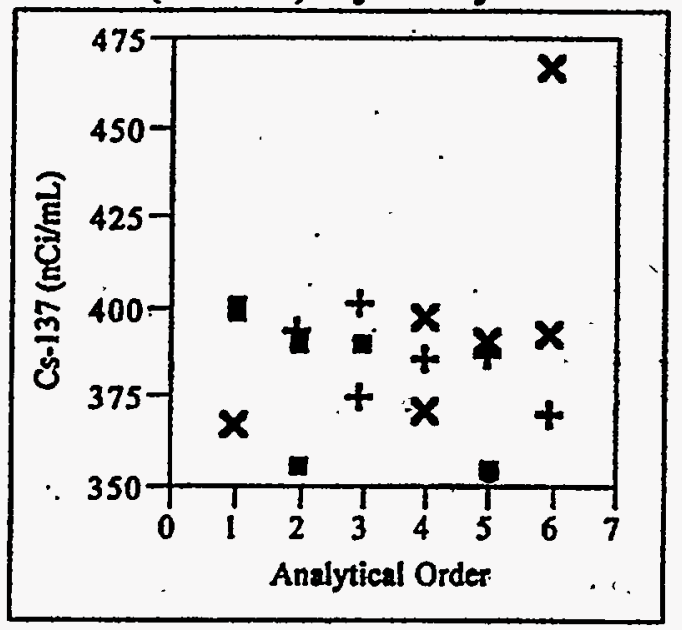

B (molar) By Analytical Order

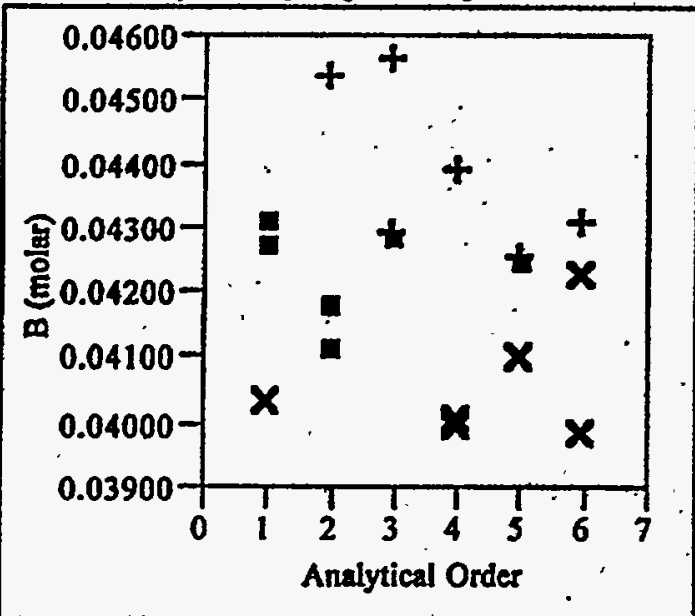

Nitrite (mplar) By Analytical Order

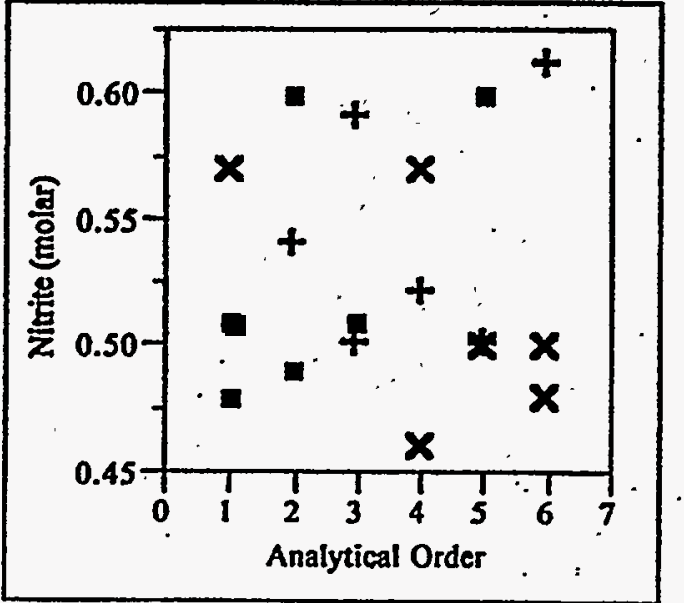

Free OH (mólar) By Ánalytical Order

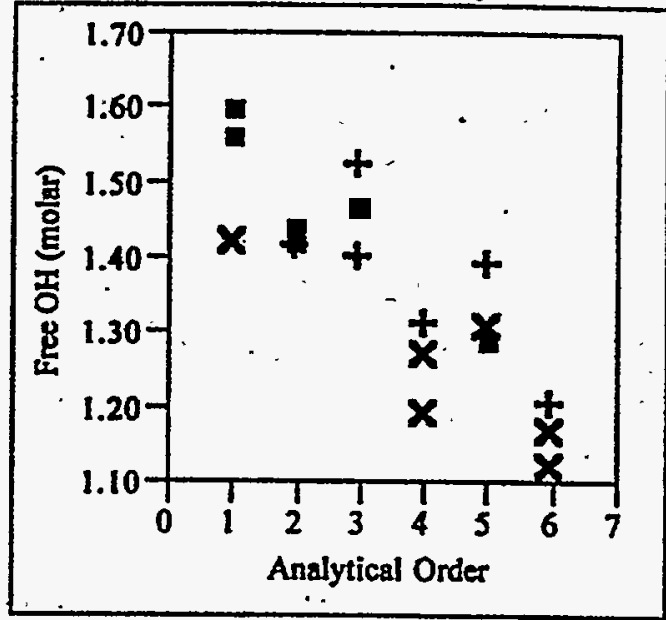

Nitrate (molar) By Analytical Order

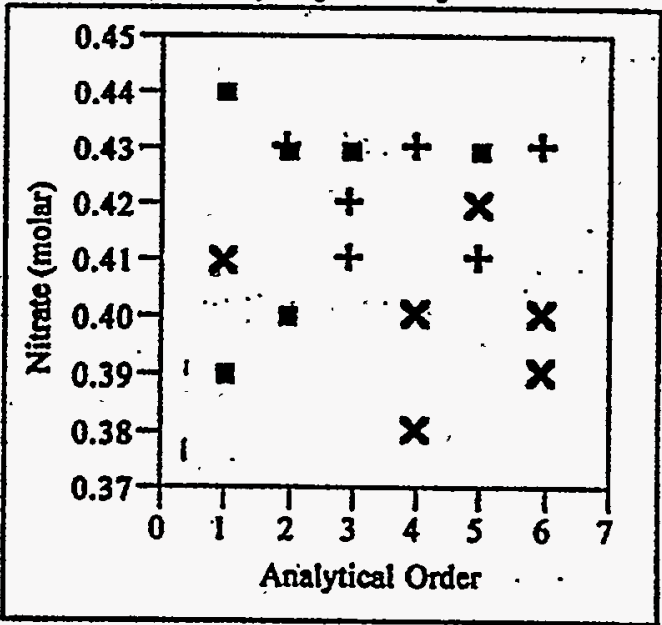

K (mmolar) By Analytical Order

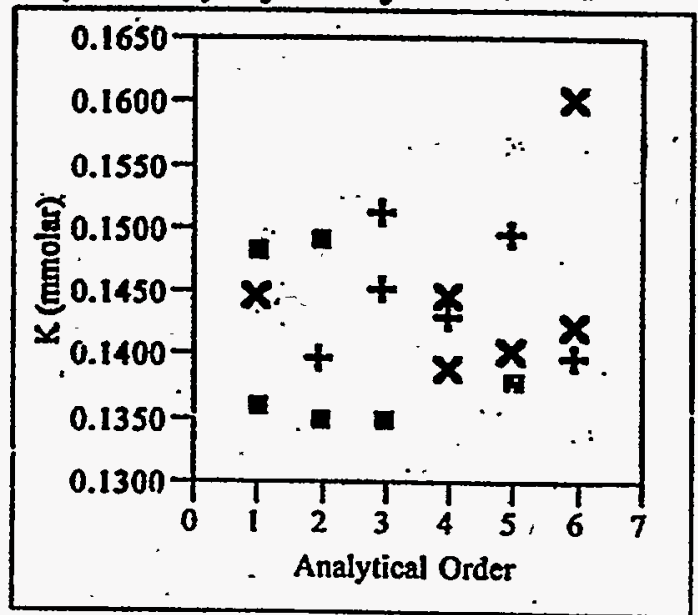




\section{Exhibit 17. Analyte Measurements in Analytical Sequence} (Continued)

Phenol (molar) By Analytical Order

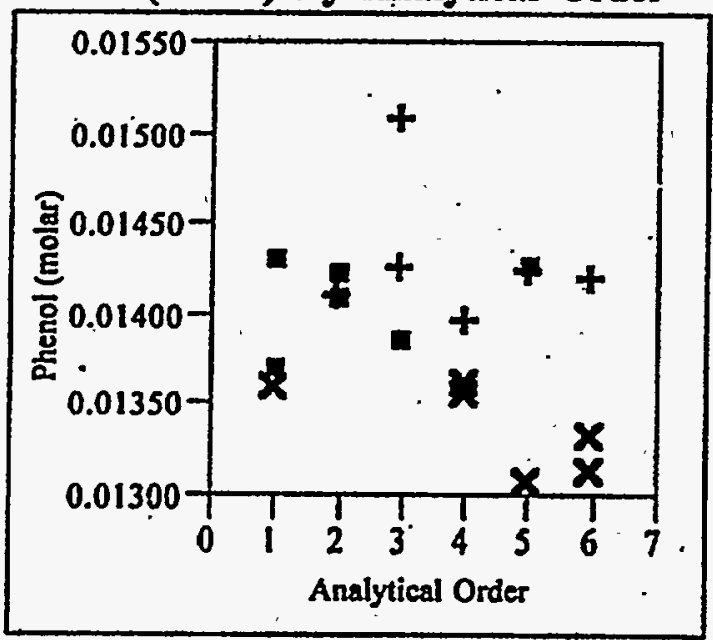

IPB (mmolar) By Analytical Order.

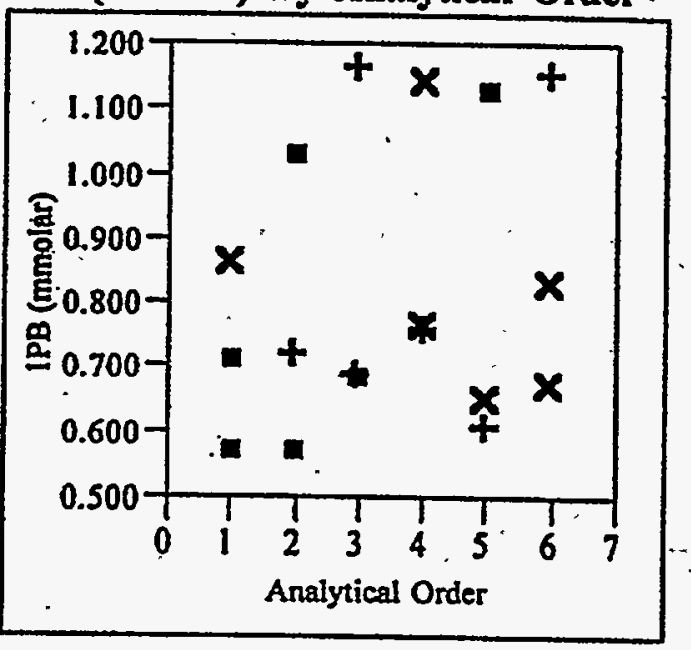


Retention: Permanent

CC: D. B. Amerine, 704-56H

K. Andringa, 773-41A

J. I. Barmes, 704-S

M. J: Barnes; 773-A

A. L. Blancett, 773-A

W. T. Boyce, 773-A

T. E. Britt, 732-B

B. T. Butcher, 773-43A

J. T. Carter, 704-25S

G. I. Cauthen, 241-119H

W. C. Clark, 704-56H

P. F. Cloessner, 773-A

C. J. Coleman, 773-43A

C. I. Crawford, 773-41A

D. P. Diprete, 773-41A

D. E. Doughty, 704-56H

I. O. Dworjanyn, 779-2A

S. J. Eberlein, 704-56H

T. B. Edwards, 773-42A

A. A. Ekechukwu, 773-A

H. H. Elder, 704-S

T. J. Fiske, 241-120H

J. R. Fowler, 704-Z

F. R. Graham, 773-A

J. C. Griffin, 773-A

M. S. Hay, 773-A

M. J. Hitchler, 730-2B

D. T. Hobbs, 773-A

E. W. Holtzscheiter, 773-A

C. W. Hsu, 773-A

M. L. Hyder, 773-A

R. A. Jacobs, 704-T

M. D. Johnson, 704-56K

M. T. Keefer, $704-56 \mathrm{H}$

E. A. Kyser, 773-A

I. F. Landon, 704-T

T. J. Lex, 719-4A

I. S. Iivingston, 703-H

P. E. Lowe, 773-41A

J. C. Marek, 704-T

D. J. McCabe, 773-43A

J. D. Menna, 730-2B

M. S. Miller, 704-56H

M. J. Montini, 704-56H

J. P. Morin, 719-4A

C. A. Nash, 676-1T

L. M. Nelson, . 773-43A

L. M. Papouchado, 773-A

R. A. Peterson, 773-A

S. F. Peterson, 773-41A
C. T. RandalI; 704-T

P. I. Rutland, 242-152H

R. M. Sátţerfield, 719-4A

W. E. Stèvens, 773-A

P. C. Suggs, 703-H

R. F. Swingle, 773-A

W. L. Tamosaitis, 773-A

M. C. Thompson, 773-A

L. L. Tovo, 773-A

R. C. Tuckfield, 773-42A

W. B. Vanpelt, 676-1T

D. D. Walker, 773-A

M. J. Witaker, 773-A

A. W. Wiggins, 241-152H

W. R. Wilmarth, -773-42A

A. I. Wooten, 732-B

G. T. Wright, 773-A

TIM, 703-43A

LWP Files c/O A. Patterson, 773-A

ITP Files c/o A.G. Wiest, 241-119H 